\title{
Evidence for interspecific hybridization in bryophytes during pre-molecular and molecular eras
}

\author{
WEERACHON SAWANGPROH ${ }^{1} \&$ NILS CRONBERG ${ }^{2 *}$ \\ ${ }^{1}$ Division of Conservation Biology, School of Interdisciplinary Studies, Mahidol University (Kanchanaburi Campus), 199 M. 9 , \\ Lumsum, Sai Yok District, Kanchanaburi Province, Thailand \\ "weerachon.saw@mahidol.ac.th; 내ttps://orcid.org/0000-0002-6345-2034 \\ ${ }^{2}$ Biodiversity, Department of Biology, Lund University, SE-223 62 Lund, Sweden. \\ *Corresponding author: "= nils.cronberg@biol.lu.se; @ ittps://orcid.org/0000-0002-3369-8420
}

\begin{abstract}
Interspecific hybridization had been long recognized as a widespread evolutionary process in vascular plants. In the present review, we summarize knowledge concerning studies of interspecific hybridization in bryophytes before and after the advent of molecular methods. The available data indicate that hybridization is an important evolutionary phenomenon among bryophytes. Evidence for hybridization events before the molecular era is mainly based on studies of intermediacy of parental morphology. The recent molecular marker technology has revolutionized studies of hybridization, generating new insights into the genetic and evolutionary consequences of homoploid and allopolyploid speciation. The current molecular approaches support the prevalence of allopolyploidy in bryophytes. However, we anticipate that homoploid hybridization is under-reported. Finally, we suggest some directions for future studies of hybrid speciation among bryophytes.
\end{abstract}

Key words: Allopolyploid, bryophytes, homoploid, interspecific hybridization, introgression, molecular marker

\section{Introduction}

For many years, natural interspecific hybridization has been considered an important process in plant, animal and fungal evolution (Gross \& Rieseberg 2005; Mallet 2007; Soltis \& Soltis 2009, Schmickl et al. 2017), and it is estimated that more than $50 \%$ of vascular plant species (Stebbins 1950) and about of $50-70 \%$ of flowering plant species have some form of hybrid origin (Stace 1987). Based on recent genetic evidence, hybrid speciation is more common than earlier expected not only in plants but also in animals (Mallet 2007). In nature, some hybrid progeny is soon lost by natural selection, but others may survive beyond the initial generation by intercrossing between other hybrids forming "hybrid zones" and sometimes backcrossing with parental genomes forming "hybrid swarms" (Rhymer \& Simberloff 1996). Repeated backcrossing of a hybrid with one of its parent species (introgression) may transfer genes between different evolutionary units. Hybridization and introgression (sometimes collectively called 'introgressive hybridization) contribute to an increase of intraspecific genetic diversity (Anderson 1948), genetic adaptation (Stebbins 1950), increase of genetic, ecotype and species diversity (Dobzhansky 1937; Mayr 1942; Grant 1981; Whitham et al. 1994; Coyne \& Orr 2004; Natcheva \& Cronberg 2004; Wissemann 2007) or hybrid breakdown or reinforcement of reproductive barriers between closely related taxa (Ellstrand \& Elam 1993; Rieseberg \& Gerber 1995; Levin et al. 1996; Petit et al. 1999). Hybridization could also lead to extinction through genetic swamping, the loss of a rarer species, when subject to hybridization and back-crossing to a more common species, or demographic swamping, when excess production of maladapted hybrid progeny causes population decline (Todesco et al. 2016).

By definition, hybridization is a union between differentiated genetic materials in new individuals derived from parents which belong to different species, subspecies (Rieseberg 1997; Wagenitz 2003) or distinct populations (Arnold et al. 1991). Empirical data implies that hybridization has an important role in speciation (Mallet 2007, reviewed in Wissemann 2007). Two principal types of hybrid speciation are generally recognized, allopolyploidy and homoploid (recombinational) hybrid speciation (Mallet 2007; Hegarty \& Hiscock 2005). Allopolyploidy involves hybridization between two taxa, in which hybrid offspring acquires a genome composed of more or less the full chromosome sets 
of both the parental individuals. The processes involved in allopolyploidy are well documented and a large body of knowledge has accumulated over the past history. Homoploid hybrid speciation involves a union between two taxa without change in chromosome number and is associated with recombination of the parental genomes.

Bryophytes constitutes the second most diverse group of higher plants, followed only by flowering plants, with some 20,000 species globally. They consist of three remotely related major groups, mosses (Bryophyta), liverworts (Marchantiophyta) and hornworts (Anthocerotophyta) (Nickrent et al. 2000; Kugita et al. 2003), which represent evolutionary lineages related to the first algal colonizers of terrestrial habitats. The relevance to bring them together in the context of hybridization is that they share a similar life cycle in terms of a dominant haploid gametophytic phase and a short-lived diploid sporophytic phase which is physically attached to the female parent. Bryophytes can reproduce both sexually and vegetatively. The sexual reproduction of bryophytes depends on water, by which mobile male gametes can swim to fertilize sessile female gametes. Successful fertilization of bryophytes is determined by both water availability and distance between male and female plants. This means that species that are involved in hybridization must grow in close vicinity, which is sometimes the case in intermediate or mosaic habitats (reviewed in Natcheva \& Cronberg 2004).

Interspecific hybridization in bryophytes occurs after fertilization and the resulting diploid hybrid sporophyte is physically connected to the haploid female gametophyte (Nicholson 1931; Anderson 1980). The two paternal genomes are recombined during numerous meiotic events taking place in the sporophyte prior to the formation of spores. Thus, the true hybrid is the sporophyte (comparable to the F1 generation in of angiosperms with hybrid origin) and the spores are referred to as "recombinants" or "hybrid segregates" (comparable to the F2 generation of angiosperms), containing a combination of genes from both parents. If viable, recombinant spores may germinate and develop into the haploid gametophytes, which are directly exposed to natural selection since no variants are hidden as recessive alleles.

Long-term impacts of hybridization depend on circumstances, for example, it may slow or reverse genetic differentiation by allowing gene flow and recombination between species. Hybridization may also accelerate speciation by adaptive introgression or give rise to near-instantaneous speciation by allopolyploid formation (Abbott et al. 2013). Although speciation by homoploid hybridization is considered rare, sporadic hybridization is well documented to mediate horizontal transfer of adaptive genetic variation in both plants and animals (Burke \& Arnold 2001).

Interspecific hybridization was long ignored by bryologists as an evolutionary process although hybrids were identified based on morphological characters already in the mid 1800s (Natcheva \& Cronberg 2004). In most of the first observed cases, which included fairly distantly related species, hybrid breakdown took place during sporophyte initiation or spore formation, leading to a general conception that bryophyte hybrids were evolutionary insignificant failures. Hybridization in bryophytes was claimed more common following the discovery of allopolyploid species (Persson 1954; Wyatt 1994). Homoploid hybridization is historically rarely reported in bryophytes, even though its presence has been well-established in several groups of vascular plants (Anderson \& Stebbins 1954; Grant 1981; Buerkle et al. 2000; reviewed in Natcheva \& Cronberg 2004; Mallet 2007). In the present review, we aim to summarize different kinds of evidence among various groups of bryophytes in both nature and in vitro, both before and after molecular era. We survey the two major types of hybrid speciation processes in bryophytes (allopolyploid vs. homoploid). We account for the prevalence of different methods for detection of bryophyte hybridization in a historic perspective. The objective is also to provide prospects for future bryological studies on hybridization.

\section{Materials and methods}

To retrieve articles that report natural and experimental interspecific hybridization among bryophytes, we performed online-searches for full articles or abstracts from the databases Web of Science ${ }^{\circledR}$ and Google Scholar (available at http://scholar.google.com/). We also collected references that were cited by various authors that did not appear in the above-mentioned searches. Keywords, i.e. "Bryophyte + Hybrid" "Bryophyte + Hybrid + Hybridization" "Bryophyte + Interspecific Hybridization" "Bryophyte + Allopolyploid" "Bryophyte + Homoploid", were chosen for searches in the databases. The time span for searches was set from early 1900's until September 2020. 


\section{Results and discussion}

Based on our literature search we found 207 records dealing with bryophyte hybrididzation in 132 articles, including for example, observations in nature, hybrid specimens from museum vouchers, experimental cross fertilization, spontaneous fertilization and hybridization detection by various molecular tools (Appendix 1). Records of hybridization are not evenly distributed among taxonomic groups - a large proportion of (putative) hybrids and their (putative) parental species belong to the acrocarpous moss groups (108 records) and peat mosses ( 54 records) and thallose liverworts ( 25 records). Notably, we found no record of hybridization in hornworts (Fig. 1). The three moss families most frequently reported to hybridize are Sphagnaceae, Funariaceae and Pottiaceae (Fig. 2). The three most studied bryophyte families prior to the molecular era are Funariaceae, Pottiaceae, and Bryaceae, whereas the three most studied bryophyte families during the molecular era are Sphagnaceae, Pottiaceae and Mniaceae (Fig. 3).

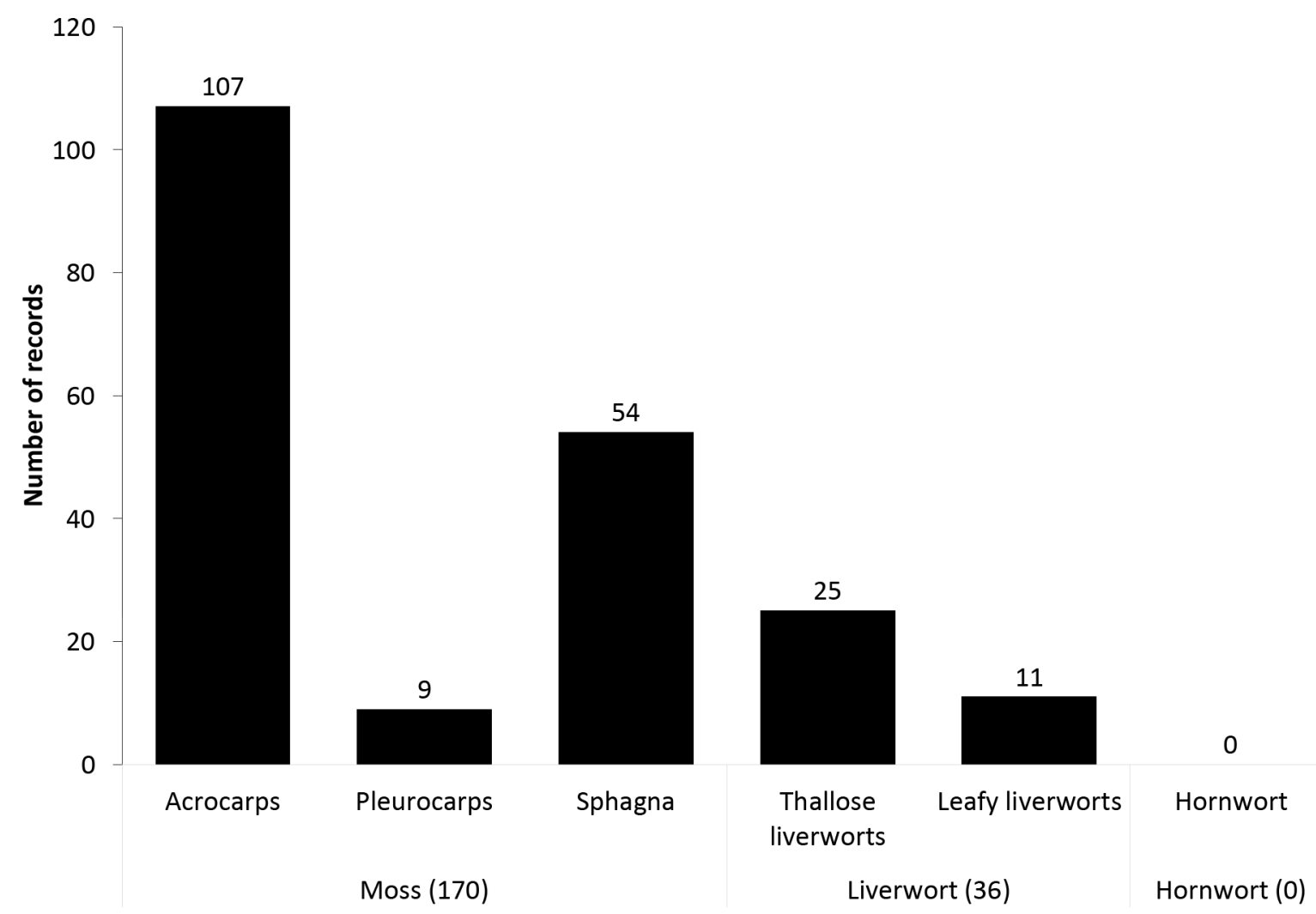

FIGURE 1. Number of literature records of interspecific hybridization in bryophytes categorized by growth form.

Initially, hybrid identification was based solely on morphological studies or a combination of morphology and spore germination/spore characters, subsequently by cytological ploidy level determination and analyses of secondary chemical substances and more recently by DNA markers at the turn of the $20^{\text {th }}$ century (Fig. 4). Therefore, we divide the records into two major periods - the first period during 1900-1988 (Pre-molecular era) and the second period during 1989-present (Molecular era) (Fig. 4).

\section{Recognizing hybrid offspring in bryophytes in the pre-molecular and molecular periods}

First period (1900-1988): Hybrid characterization based on morphological intermediacy of sporophytes, gametophytes, spore characters, spore germination test and/or chromosome counts.

During this period hybrid identification was mainly restricted to morphological studies or a combination of morphological studies and other methods (Appendix 1). Morphological observations were used as preliminary indicators of hybridization, which was subsequently confirmed by complementary and more reliable methods. In quantitative terms we see that the markers that were used for identifying hybrid offspring in bryophytes are based on five key characters e.g. 1) sporophyte morphology 2) gametophyte morphology 3) F1 spore viability 4) F1 spore 
morphology and 5) ploidy level, respectively (Appendix 1). Observations of hybrid morphology in bryophytes during this period were made by looking for a combination of traits characteristic of the putative parental species:

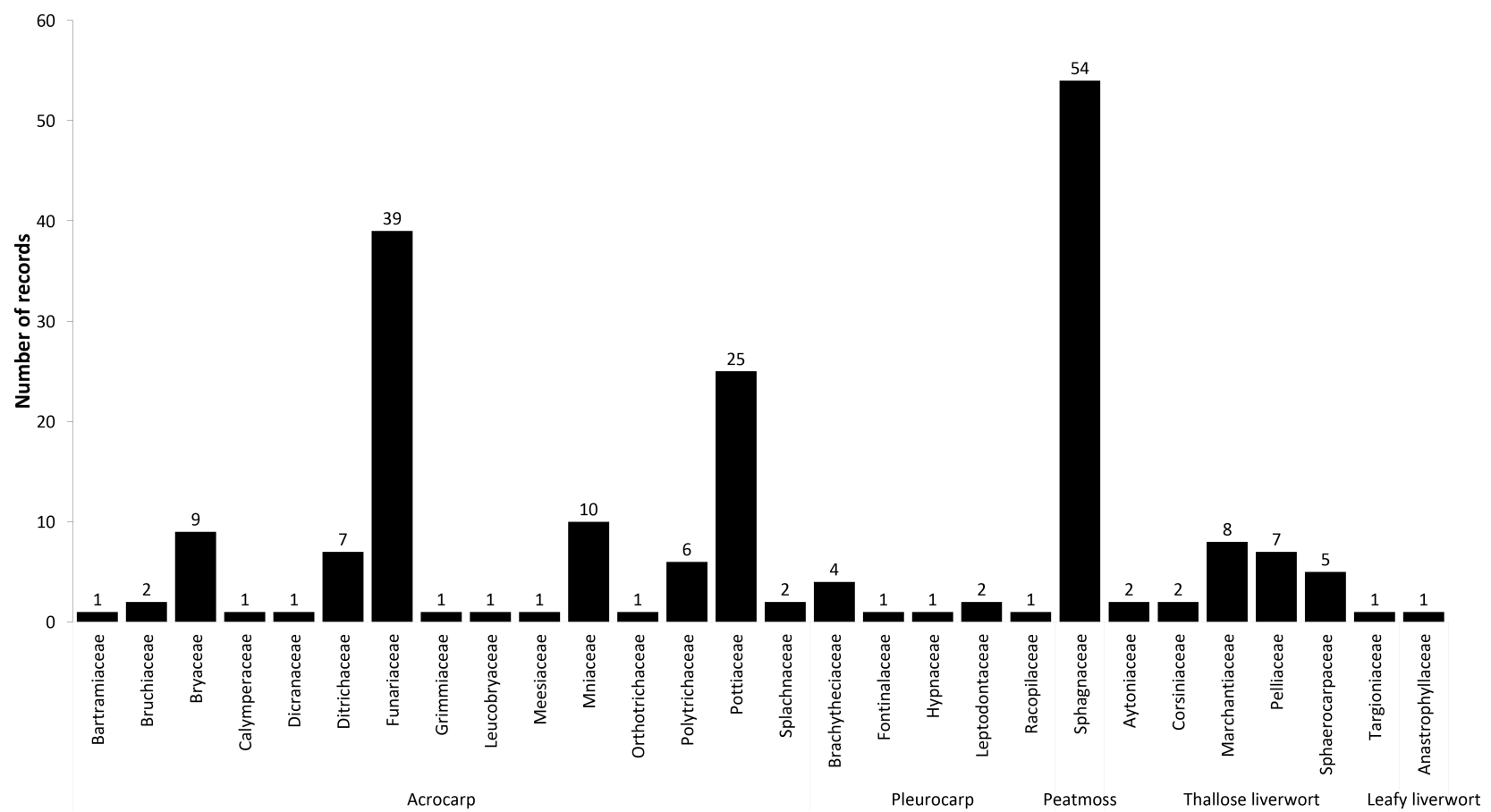

FIGURE 2. Number of literature records of interspecific hybridization in bryophytes categorized by family.

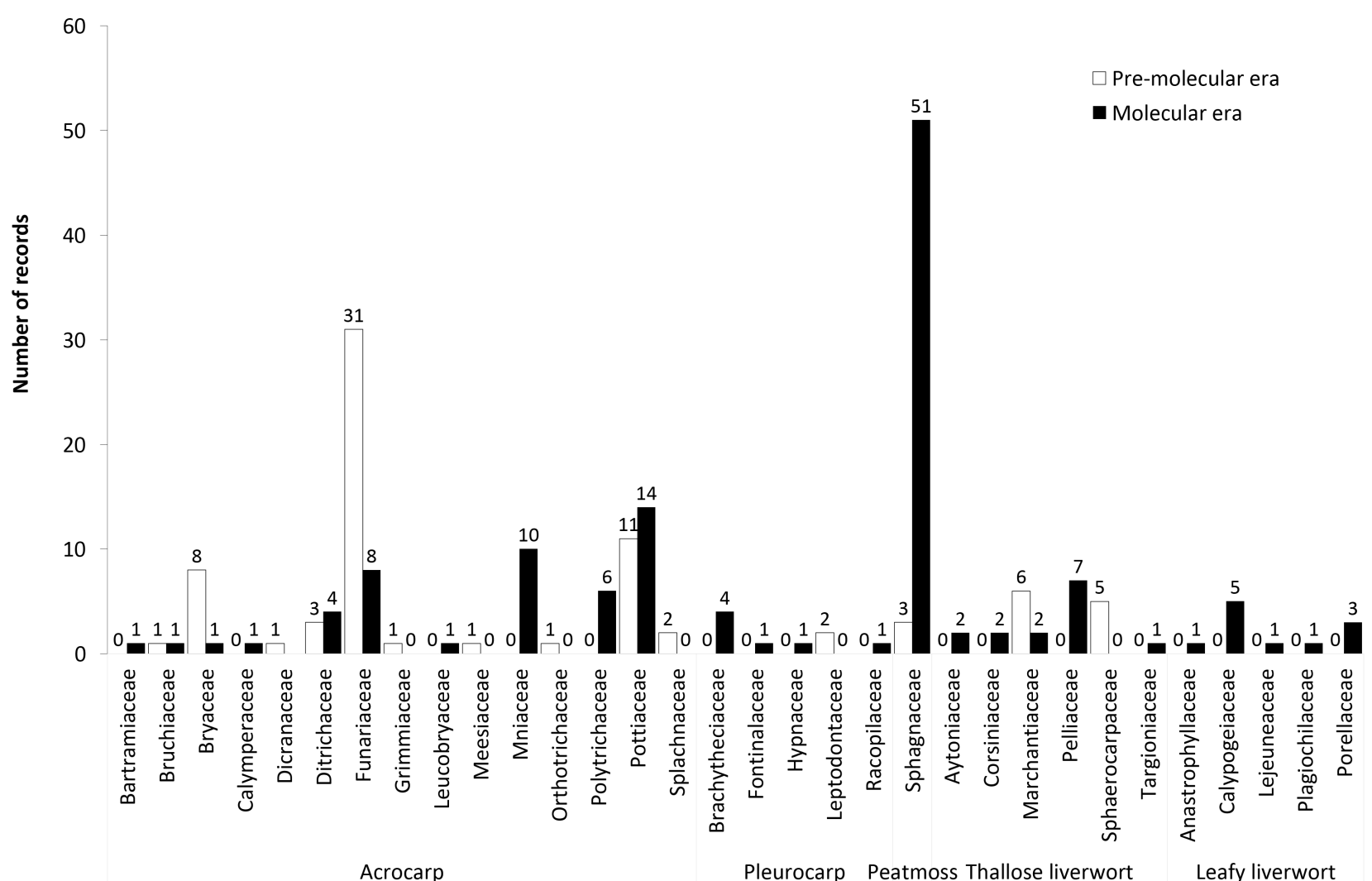

FIGURE 3. Comparison of the number of literature records of interspecific hybridization in bryophytes during the premolecular and molecular eras categorized by family. 


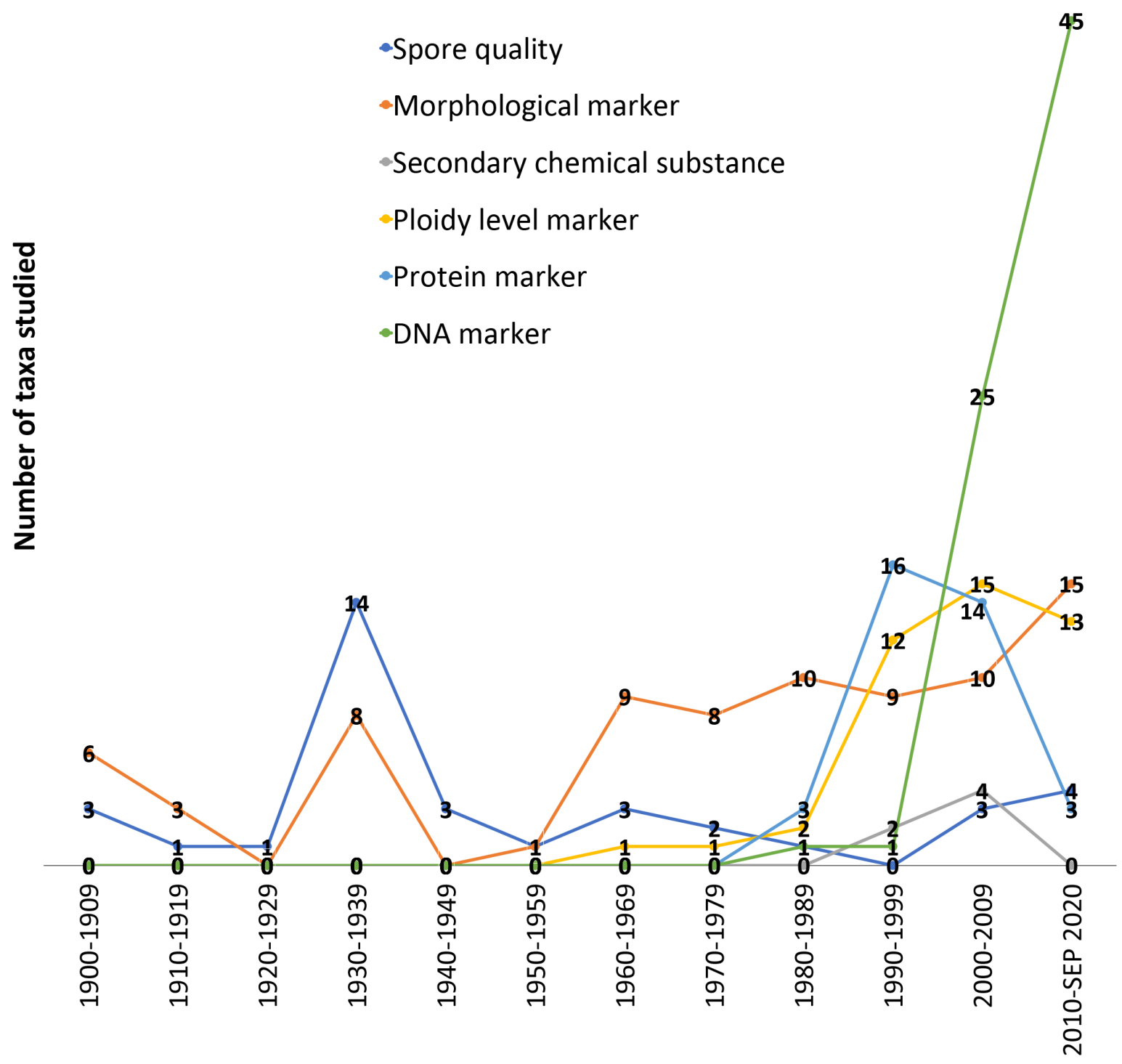

FIGURE 4. Number of literature records of hybrid progeny in bryophytes recognized by each type of character (marker).

\section{i. Hybrid sporophytes}

In most reported cases (Appendix 1), hybrid sporophytes were intermediate in terms of external and internal morphology (Allen 1935), capsule colour (Allen 1935), seta colour and presence/absence of calyptra (Pettet 1964), capsule shape (Khanna 1960; Anderson \& Lemmon 1972; Hedderson 1986), form, colour and anatomical structure of seta in cross section (Frisvoll 1978), numbers and positions of stomata on capsule walls (Hedderson 1986) or exothecial cell characters (Andrews \& Hermann 1959; Frisvoll 1978; Hedderson 1986). Generally, the hybrid sporophytes showed intermediate characters of both parents (Allen 1935), but there are some exceptions where hybrid sporophytes closely resembled the female parent (Allen 1935; Doyle 1960). If sought for, intermediate sporophytes were rarely encountered in nature (Crundwell \& Nyholm 1964; Pettet 1964). The rare observation of intermediate sporophytes means that it is difficult to assess the evolutionary significance of these reports. In addition, hybrid sporophytes with intermediate characters will remain undetected if closely related parental species have similar sporophytes, which is the case in many acrocarps, most pleurocarps, peat mosses, and almost all liverworts (Natcheva \& Cronberg 2004).

\section{ii. Hybrid gametophytes}

In bryophytes it is often difficult to assess whether morphological intermediacy has arisen as a consequence of 
plasticity, ecotypic differentiation or hybridization. Hybrid gametophytes (also known as recombinant gametophytes) with intermediacy of parental character combination are therefore rarely reported according to Natcheva \& Cronberg (2004). Gametophyte characters used to identify hybrid gametophytes include shape of leaves (Khanna 1960), gemma colour (Crundwell \& Nyholm 1964), leaf arrangement (Holmen \& Scotter 1971), and numbers of rhizoidal tubers (Risse 1985). Gametophytic morphology generally shows high phenotypic plasticity in bryophytes (Campbell 1971; Vanderpoorten \& Goffinet 2009. In more than half of the articles (Appendix 1), gametophytes of putative hybrid origin showed an intermediate mix of parental characters, but several articles instead reported hybrid gametophytes to more closely resemble the female parent (Nicholson 1910; Wettstein 1928; Allen 1935; Pettet 1964; Holmen \& Scotter 1971; Anderson \& Lemmon 1972). Two exceptions included 1) Physcomitrium (haploid) $\times$ Funaria (haploid); the haploid gametophytes from hybrid spores showed similar characters to the female parent but diploid gametophytes from hybrid spores showed similar characters to the male parent (Allen 1935), and 2) Bryum rubens $\times$ Bryum microerythrocarpum (maternal/paternal unknown); the hybrid gametophytes produced gemmae that were similar to those of $B$. rubens (Crundwell \& Nyholm 1964).

\section{iii. F1 hybrid spores}

Many cases of F1 hybrid spores were detected in bryophytes during the first period (Appendix 1). Inference of hybridization from spores was generally based on two types of observations; a) spore quality assessment via germination experiments, and b) studies of spore morphology (size and shape). Hybrid spores are frequently imperfect and wrinkled (Andrews \& Hermann 1959; Reese \& Lemmon 1965; Hedderson 1986), show a high degree of sterility (Nicholson 1905, 1906; Allen 1935, 1945; Nyholm 1954; Crundwell \& Nyholm 1964; Williams 1966; Anderson \& Lemmon 1972), and a variable degree of developmental disorder after germination (Andrews 1918; Burgeff 1943), suggesting that there is an internal sterility barrier to hybridization (Smith 1978). Typically, spore germination was investigated only on putative hybrid species but not systematically compared with that of the putative parental species (Appendix 1). Hybridization often result in sterile or inviable progeny owing to divergent evolution and genomic incompatibility (Mallet 2007), but spores could be inviable for other reasons than hybridization and some species are known to show large within-species variation in spore fertility (for example Ceratodon purpureus; Norrell et al. 2014) Furthermore, Allen (1935) reported that (putative) hybrid spores sometimes displayed a high germination rate ( $\geq 50 \%)$. As for the size, hybrid spores did not always show intermediate size of the parents, but rather spore size classes associated to each of the parents in the same hybrid capsules (Allen 1935), variable sizes of spores in the same hybrid capsules (Nyholm 1954; Andrews \& Hermann 1959) or spore size similar to the female parent (Doyle 1960).

Unlike hybrid sporophytes and gametophytes, morphological intermediacy of hybrid spores between two putative parental taxa is rarely reported. Spore morphology is rarely useful below the genus level in mosses, and more important as diagnostic character in acrocarpous than pleurocarpous species (Clarke 1979; Ireland 1987). Some hepatics, especially thallous liverworts have species-specific spore morphology. Studies performed by Allen (1930) on external morphology of spores from the dioicous liverwort genus Sphaerocarpos demonstrated maternal inheritance of this trait (actually, said to be the first example of maternal inheritance in plants). Consequently, spore wall markings resembled spores belonging to the female parent rather than the male parent in cross experiments between Sphaerocarpos species (Doyle 1960).

\section{iv. Hybrid bryophytes with different ploidy levels}

Chromosome numbers in bryophytes are either studied in mitotic gametophyte cells or meiotic spore mother cells (Smith 1978). Observations on bryophyte chromosomes are time consuming and sometimes lead to inaccurate results (Smith 1978). From our literature search, Khanna (1960) was the first to provide evidence of allopolyploidy in bryophytes by chromosome counts from spore mother cells. Detection of hybrid species by ploidy level estimates based on chromosome counts alone might be problematic unless the karyotypes are distinctly different; 1) chromosome counts usually fail to differentiate between autopolyploids (containing more than two complete sets of homologous chromosomes and multisomic inheritance) and allopolyploids (contain separate sets of non-homologous chromosomes resulting from hybridization between different species and displaying disomic inheritance) (reviewed in Såstad 2005); 2) estimates of DNA content from chromosome counts is inclined to uncertainty due to a lack of overall relationship between chromosome number and genome size for mosses and a lack of cytological evidence for polyploidy in bryophytes containing high chromosome numbers (Vogelmayer 1998). Accordingly, Vogelmayer (1998) suggested that chromosomal rearrangements, such as translocations and deletions are the most common reason for differences in chromosome numbers, and that polyploidization may be important only in certain families and genera of bryophytes (e.g. Sphagnaceae). Såstad (2005) added that estimation of ploidy level by chromosome counting may be flawed by 
chromosome fission and fusion events. In the case of liverworts, which have a more stable basic chromosome number of 8, 9 or 10, it is easier to assess if genomes are haploid or polyploid (Schuster 1966; Smith 1978; Newton 1983).

\section{Second period (1988-present): Hybrid characterization based on combined methods of cellular ploidy determination, biochemical properties and genetic markers (biological and molecular markers).}

From 1988 to the present days, hybrid progeny identification based on combined morphology of parental species characters in sporophytes, gametophytes and F1 spores are still practiced for screening of hybrids, but lose in popularity (Appendix 1). Ploidy level analysis based on various microscopic methods (see below) is more widely used to confirm species hybridization through allopolyploidy in this period than the first period. At the same time, more precise methods for identification of hybrids in bryophytes are introduced: protein markers (e.g. isozymes), DNA markers (e.g. microsatellite DNA, nuclear DNA, cpDNA, mtDNA, SNPs) and cell chemical markers (e.g. flavonoids, oil bodies) (Appendix 1). Protein markers were gradually replaced by DNA markers, whereas secondary chemical substance markers were only used for a short period (Fig. 2). The various markers to identify bryophyte hybridization events in the second period are summarized below.

\section{i. Hybrid sporophytes}

Recognition of hybrid sporophytes based on intermediacy of parental species characters is rare during this period. In case of non-intermediacy, hybrid sporophytes showed similarity to one parent (McIntosh 1989), variable characters (van der Velde \& Bijlsma 2004), or more robustness than both parents (Flatberg et al. 2006; Ricca et al. 2011). Thus, observations of intermediate characters of sporophytes are used rather as a preliminary screening method for hybrid species preceding other more accurate investigations (Appendix 1).

\section{ii. Hybrid gametophytes}

Hybrid gametophytes or recombinant gametophytes with parental character combination are rather frequently reported in various taxa in our survey (Appendix 1). Gametophyte characters chosen to identify hybrid gametophytes include the pattern of sex organ arrangement (Lobachevs'ka \& Ulychna 1994), thallus cell size (Boisselier-Dubayle et al. 1998a; Orzechowska et al. 2006), leaf size (Såstad et al. 2001), anatomy of stem cross section (Werner et al. 2014). In general, gametophytic characters mentioned in the surveyed literature show high phenotypic plasticity. In cases of non-intermediacy, hybrid gametophytes showed different degrees of parental character inheritance e.g. highly variable (Shaw \& Bartow 1992; Cronberg 1996; Boisselier-Dubayle et al. 1998b), similar to female parent or one parent (Delgadillo 1989; Ros et al. 1994; Ricca \& Shaw 2010; Shaw et al. 2012b; Shaw et al. 2013; Werner et al. 2014), indistinct to non-hybrid populations (Boisselier-Dubayle \& Bischler 1998; Boisselier-Dubayle \& Bischler 1999), or more robust size than both parents (Boisselier-Dubayle et al. 1998a; Såstad et al. 2001; Orzechowska et al. 2006). Like hybrid sporophytes, morphological identification of hybrid gametophytes is used as a complementary method, together with other more reliable studies.

\section{iii. F1 hybrid spores}

Hybrid spores were reported in some cases of bryophyte species in the second period but did not increase over time (Appendix 1). Hybrid spores with non-intermediate sizes showed more highly variable sizes than those of their parents (Delgadillo 1989; Košnar et al. 2012) or similar sizes to those of one parent (often female) (Guerra et al. 1994; Ros et al. 1994) or larger spore size than those of the parents (Flatberg et al. 2006) or the same size and shape as their parents (Natcheva \& Cronberg 2007a, b) or irregular size and shape compared to the parents (Frahm \& Ho 2010).

\section{iv. Hybrid bryophytes with different ploidy level}

Earlier cytological techniques are gradually replaced by improved methods to compare chromosome morphology, ploidy level and estimate DNA content e.g. the squash technique (Boisselier-Dubayle \& Bischler 1998; BoisselierDubayle et al. 1998a; Boisselier-Dubayle et al. 1998b; Orzechowska et al. 2010), the fluorochrome 4, 6-diamidino-2phenylindole (DAPI) technique (Abderrahman 1998; Abderrahman 2004; Buczkowska et al. 2004), flow cytometry (Såstad et al. 2001; Ricca et al. 2008; Karlin et al. 2009; Košnar \& Kolář 2009; Orzechowska et al. 2010; Ricca et al. 2011; Buczkowska et al. 2012; Nieto-Lugilde et al. 2018), Fluorescent differential staining, C-banding and fluorescent in situ hybridization (FISH) with 26S and 5S ribosomal DNA probes (Orzechowska et al. 2010), Feulgen DNA image densitometry (Ricca et al. 2008; Karlin et al. 2009; Kyrkjeeide et al. 2019) and ploidy estimation by microsatellite pattern (Karlin et al. 2013, 2014). The use of fluorescent in situ hybridization (FISH) of specific DNA probes to specific chromosomes or chromosome segments has recently proved straightforward and useful in studies of 
chromosomal rearrangements and homologue associations, which can generate chromosome maps for the subsequent study of chromosome evolution during hybridization event (Lysak et al. 2001; Hegarty \& Hiscock 2005) (Appendix 1).

\section{v. Hybrid bryophytes with different concentration of secondary chemical substances}

Wyatt and his colleagues in 1991 were the first to use flavonoids to study hybridization among seven taxa of Plagiomnium section Rosulata and found that hybrids express a combination of the flavonoids characteristic of their parental species. Buczkowska et al. (2004) demonstrated that the distribution pattern of oil bodies (presence/absence) in leaf and underleaf cells were highly correlated with isozyme variants of four enzymes of six Calypogeia liverwort species from Poland. The fixed heterozygosity pattern of two enzymes (TPI and GOT) found in all studied samples of the polyploid C. azurea, C. muelleriana and C. sphagnicola may suggest the three species having allopolyploid origins.

\section{vi. Hybrid bryophytes via molecular marker studies}

Gradually improved molecular techniques have over the years become employed for studies of variation and hybridization at the genomic level in flowering plants (Hegarty \& Hiscock 2005) and bryophytes (Pardo et al. 2014). Starting around 1988, a range of molecular techniques based on various kinds of markers have been used to identify hybrid progeny in bryophytes. Marker-based techniques to identify hybrids assume that the given markers are speciesspecific to either parent, in order to be detected in combination in putative hybrids. Molecular markers can be divided into two major classes 1) protein markers (e.g. isozymes or allozymes) and 2) DNA markers such as RFLPs, RAPDs, Microsatellites, ISSR, PCR-RFLP, QTL-associated markers, specific DNA sequences, and SNP markers.

Isozymes or allozymes. The isozymes were important sources of information about infraspecific population structure and genetic relationships among species because they are cost-effective, easy to detect, highly reproducible (Shaw 2009; Gibson 2015), and co-dominant so that diploid/polyploid individuals can be identified as homozygotes or heterozygotes at a given locus (Parker et al. 1998). Wyatt et al. (1988) introduced isozymes as molecular markers to identify interspecific hybridization and chromosome doubling in the moss, Plagiomnium medium. Due to co-dominant expression, allopolyploids were readily identified by fixed heterozygosity at multiple loci. Isozyme analyses have been replaced by DNA markers in recent years, although useful in studies of hybrid speciation in conjunction with other techniques such as RFLP analysis of chloroplast DNA, RAPD and microsatellite assays. (Appendix 1).

Restriction Fragment Length Polymorphisms (RFLPs). RFLPs were the first widespread markers that quantified variation in DNA sequences by using restriction enzymes to cut DNA into small pieces and then run in agarose gel and to see DNA profiles. Wyatt et al. (1988) used chloroplast DNA (cpDNA) extracted from three Plagiomnium species to identify $P$. insigne as the female parent of the alloploid $P$. medium on the assumption that cpDNA was maternally inherited. Studies of chloroplast DNA using RFLP are useful for identifying the maternity of the hybrid progeny.

Random Amplified Polymorphic $\underline{D} N A$ (RAPDs). RAPDs markers are the simplest PCR-based method by amplifying arbitrarily derived DNA segments for genotyping individuals at multiple loci (Welsh and McClelland 1990, Gibson 2015). Due to some drawbacks of this technique such as a lack of knowledge on amplification products, comigration of non-homologous fragments of similar size, a lack of reproducibility of bands and dominant nature (Shaw 2009; Pardo et al. 2014), it was soon abandoned for more accurate methods (Appendix 1). Only two studies have used RAPD technique for identifying hybrid bryophytes. Stenøien \& Flatberg (2000) and Såstad et al. (2001) indicated two progenitor species of allopolyploid species, Sphagnum troendelagicum and hypothesized that it had multiple origins from recurrent hybridization events based on a moderately high haplotypic variation in the RAPD profiles.

Microsatellites. Microsatellites (also known as simple sequence repeats, SSRs or short tandem repeats, STRs) are nucleotide tandem repeats of 1-6 bp in DNA sequences located in nuclear, chloroplast and mitochondrial genomes (Freeland et al. 2011). Van der Velde \& Bijlsma (2001) applied microsatellite markers to detect the second parental taxon of the allopolyploid hybrid acrocarpous moss Polytrichum longisetum, which was not resolved by allozyme data. The numbers of bryophyte species from which microsatellite loci have been characterized have accumulated over time, so that they have been accessible for studies of hybridization events (Appendix 1). The co-dominant property of microsatellites provides a major benefit over other markers such as RAPDs, AFLPs and ISSRs, in studies of hybridization and mating systems in bryophytes (Shaw et al. 2008c).

Inter-simple sequence repeat or ISSR. The ISSR method is similar to RAPD method but ISSR primers are designed from microsatellite regions and are longer than RAPD primers (Pardo et al. 2014), producing more reliable and reproducible bands than RAPD (Vanderpoorten et al. 2003). Natcheva \& Cronberg (2007a, b) introduced this technique to demonstrate recombination and introgression of nuclear and chloroplast genomes between the two peat 
mosses, Sphagnum capillifolium and S. quinquefarium. Recombinant progeny from hybrid sporophytes, only a few of which were viable, showed asymmetrical nuclear inheritance - possessing a majority of nuclear markers typical for $S$. capillifolium (as a paternal progenitor), whereas cpDNA markers were maternally inherited.

PCR-Restriction Fragment Length Polymorphism (PCR-RFLP). This method involved two processes, a digestion by a restriction endonuclease of a specific amplified DNA segments and the presence/absence of a given restriction site in the DNA sequence to determine polymorphism (Pardo et al. 2014). Natcheva \& Cronberg (2007a, b) used this method in their study to assess two chloroplast haplotypes in the two sympatric species of peat mosses, Sphagnum capillifolium and $S$. quinquefarium and identified gametophyte hybrids possessing a single chloroplast haplotype interited only from $S$. quinquefarium (as a maternal progenitor).

QTL-associated markers. QTL is quantitative trait loci, which refers to specific DNA regions that are responsible for controlling the expression of a quantitative phenotype (Freeland et al. 2011). McDaniel et al. (2008) demonstrated an intrinsically reproductive isolation mechanism, contributing to hybrid breakdown in interpopulation progeny of the moss Ceratodon purpureus by using markers linked to a gene that influences the expression of the quantitative trait, protonemal development size. The observations by McDaniel and his colleagues suggested that multiple complex genetic factors contribute to divergence among populations of C. purpureus.

DNA sequence markers. DNA sequence markers are more reliable than markers based on banding pattern if homologous loci are compared and paralogous genes are absent (Pardo et al. 2014). Stech \& Quandt (2010) showed that the number of markers applied in bryophytes phylogenetic studies has increased considerably since 2001, with an increase of about $250 \%$ in the plastid, $470 \%$ in the nuclear, and $550 \%$ in the mitochondrial DNA. The most difficult problem of DNA sequence marker analysis lies in the selection of the region of the genome that not only reveals allelic variation but can also be sequenced efficiently. DNA sequence markers from the three types of genomes nrDNA (nuclear), cpDNA (from chloroplasts) and mtDNA (mitochondrial) are used to study hybridization in bryophytes as shown below.

1) nrDNA markers: ITS (rRNA gene) regions are extensively used as markers because these sequences are transcribed but not translated, thus they tend to evolve rapidly and have relatively high rates of mutation that are useful for determining the phylogenies of closely related taxa (Bhatia et al. 1996). In contrast to organellar genomes (cpDNA and mtDNA), nuclear markers are biparentally inherited (Stech \& Quandt 2010).

2) cpDNA markers: Loci which are widely targeted in cpDNA sequences includes genes, spacers and introns of the following regions: $\operatorname{trnG}$, trnL, rbcL, trnL-trnF, rpL16, atpB-rbcL, rps4-trnS, trnL-F, trnH-psbA, and rpoC1 (Shaw \& Goffinet 2000; Jankowiak \& Szweykowska-Kulinska 2004; Shaw et al. 2005; Jankowiak et al. 2005; JankowiakSiuda et al. 2008; Shaw et al. 2008a,b; Bell \& Hyvönen 2010; Ricca \& Shaw 2010; McDaniel et al. 2010; Heinrichs et al. 2011; Buczkowska et al. 2012; Shaw et al. 2012a; Vilnet et al. 2012; Shaw et al. 2013; Karlin et al. 2014; Werner et al. 2014; Shaw et al. 2015). The cpDNA markers are useful in studying hybridization because they are maternally inherited (McDaniel et al 2007, Natcheva \& Cronberg 2007a).

3) mtDNA markers: The mtDNA offers few loci for bryophyte studies primarily due to lower variability as compared to the cpDNA (Stech \& Quandt 2010; Liu et al. 2012). The mtDNA genes have been used for phylogenetic studies involving genera, families, and order (Cox et al. 2004). However, some genes recently proved useful as markers for studies of species-level hybridization in bryophytes such as the trnS and the coxIII genes, the nad5 gene, and the nad4 (Jankowiak \& Szweykowska-Kulinska 2004; Jankowiak et al. 2005; Jankowiak-Siuda et al. 2008; Bell \& Hyvönen 2010). Like the cpDNA markers, the mtDNA markers are maternally inherited in bryophytes (Stech \& Quandt 2010).

Single Nucleotide Polymorphisms or SNPs. SNPs are single base pair positions in the genome that vary between individuals. Due to a high abundance in the genome, SNPs serve as useful biological markers (Jin et al. 2016). Speciesspecific SNP markers can be selected, which allow direct identification of hybrid genotypes by heterozygous allele combinations (Clarke et al. 2014; Rusek et al. 2015). Despite these obvious advantages, there are only a limited number of examples of application of SNP markers in bryophyte hybridization by 2020. SNP markers were used by Sawangproh et al. (2020a, b) to detect hybrids and to estimate the degree of genetic mixing in the pleurocarpous mosses Homalothecium lutescens and $H$. sericeum, through three generations; haploid gametophytes, diploid sporophytes and recombinant sporelings. 


\section{Records on mode of hybridization in bryophytes in the pre-molecular and molecular periods}

First period (1870-1988): Modes of hybridization (homoploid/allopolyploid) are mostly undetermined.

Studies of hybridization events based mainly on a combination of intermediate morphological characters allowed bryologists to detect parental progenitors, but usually not to reconstruct the hybridization process. Out of 76 cases of putative hybridization among bryophytes, only 14 aimed at revealing the evolutionary processes underlying the hybridization events (Appendix 1). Studies which propose a more or less well-documented mode of hybridization sum up to: allopolyploidy (11 records), autopolyploidy (5 records), homoploid origin (3 records), and allopolyploidautopolyploid combination (1 record) (Fig. 5). Smith (1978) claimed that interspecific polyploids in both mosses and liverworts seem to be autopolyploids based on cytological analyses. However, some authors disagreed with the view of prevalent autopolyploidy and argued that allopolyploidy is underestimated in bryophytes (reviewed in Wyatt et al. 1992). The modes of hybrid speciation found from our literature survey were from interpretation of cross-fertilization experiments (e.g. Doyle 1960) except one study by Khanna (1960), in which hybridization by allopolyploidy was inferred by cytological analysis through chromosome counting. The relatedness of hybridizing entities as judged by taxonomic ranking was: intraspecific (1 record), interspecific (42 records), and intersectional (36 records) (Fig. 6).

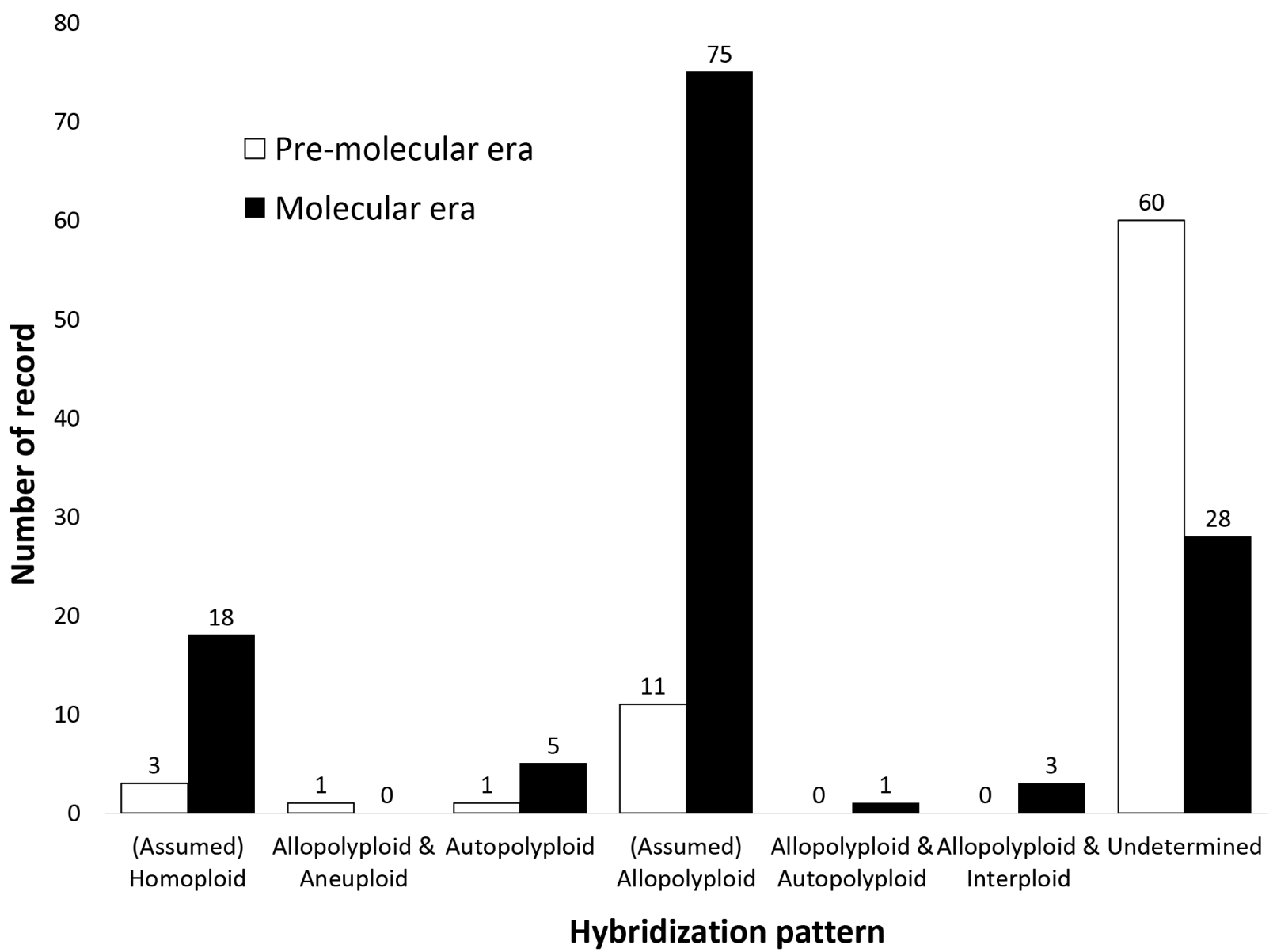

FIGURE 5. Comparison of literature records with respect to modes of hybridization in bryophytes during the pre-molecular and molecular eras.

Second period (1988-present): Modes of hybridization in bryophytes are mainly studied by more accurate methods and most of the studied cases involve allopolyploidy.

During this period, the modes of hybridization are investigated by more reliable and sophisticated cytological and molecular studies - revealing more information about the hybrid events. The cytological and molecular techniques made it possible to characterize the mode of hybridization in 101 out of 132 records (Appendix 1). The most common mode was allopolyploidy (76 records), followed by (assumed) homoploid (16 records), autopolyploid (5 records), allopolyploid-interploid combination (3 records), and allopolyploid-autopolyploid combination (1 record) respectively 
(Fig. 5). Classified by divergence level, we found hybrid records involving i) parental pair at the same ploidy level, i.e., interspecific hybridization ( 87 records) and intraspecific hybridization (14 records) and ii) the parental pair at different ploidy levels i.e., interploidal hybridization ( 2 records). Other cases were intersectional hybridization (18 records), intergeneric hybridization (10 records), and interfamiliar hybridization (1 record) (Fig. 6).

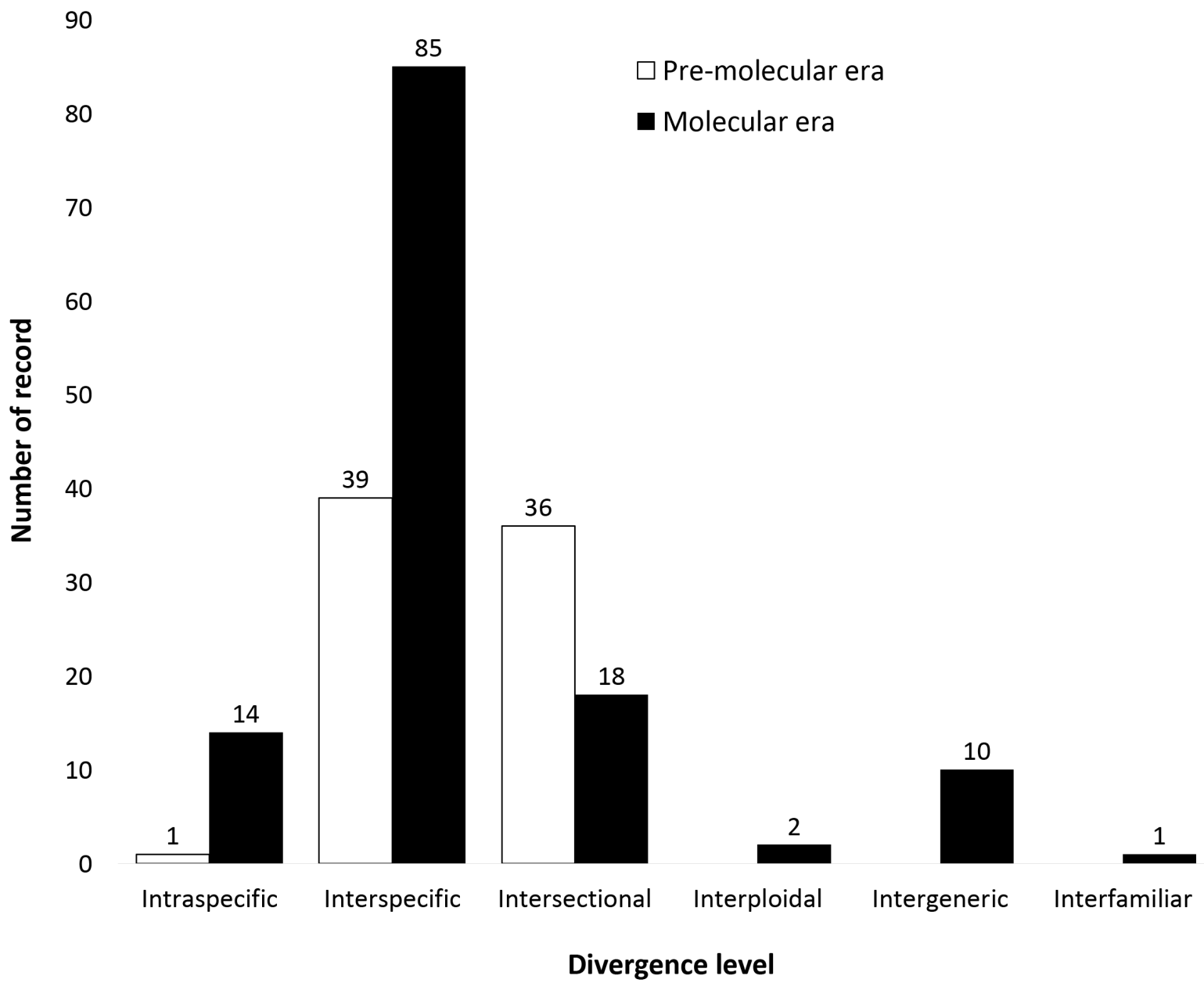

FIGURE 6. Comparison of literature records in the pre-molecular and molecular eras regarding the divergence of putative parental species to hybrids in terms of separation at different taxonomical levels.

More and more cases of hybridization by allopolyploidy are being discovered among bryophytes as cytological and molecular studies progress, following the first pioneering findings of fixed heterozygosity based on isozyme markers in Plagiomnium medium by Wyatt et al. (1988) (Appendix 1). Såstad noted in a review 2005 that all polyploid bryophytes studied so far (at the time mostly by isozymes) had turned out to be allopolyploids. He estimated that about $5-10 \%$ of liverwort species and $6-19 \%$ of moss species have polyploid origins and suggested that most are allopolyploids. Evidence for autopolyploidy is still missing among peat mosses (Sphagnum) (Meleshko et al. 2018), the most well-studied group in this respect, with a possible exception for diploid S. tescorum (Shaw et al. 2012a). The low number of confirmed autopolyploid bryophytes is puzzling, since ploidy level series exist for many taxa (Fritsch 1982), in particular among mosses. Due to the haploid-dominant life cycle in bryophytes, allopolyploidy potentially provide adaptive flexibility to hybrids by allowing heterozygosity to be expressed in the free-living gametophyte generation, unlike the haploid parents, in which the genome is directly exposed to natural selection (Wyatt et al. 1992). In theory, an allopolyploid hybridization event therefore leads to the formation of a genotype with superior fitness and a higher chance to establish and proliferate vegetatively and sexually (Natcheva \& Cronberg 2004). Shaw et al. (2008b) corroborate that allopolyploid species appear to be common among the mosses. However, speciation by homoploid hybridization is also increasingly reported among bryophytes as a result of the progress of molecular technologies. Homoploid speciation has been proposed for Physcomitrium eurystomum (McDaniel et al. 2010), Sphagnum contortum 
(Shaw et al. 2012b), Ceratodon $\times$ conicus (Nieto-Lugilde et al. 2018), but on the other hand, Linde et al. (2020) refuted on basis of genomic data the old hypothesis that Marchantia polymorpha subspecies ruderalis is a homoploid hybrid between subspecies polymorpha and montivagans. Our literature survey suggests that homoploid hybridization without speciation (admixture) may occur between differentiated geographic populations (McDaniel et al. 2008) or between more or less closely related species in the same genus (Cronberg \& Natcheva 2002; Flatberg 2005; Natcheva \& Cronberg 2007a,b; Ricca \& Shaw 2010; Shaw et al. 2012a,b; Meleshko et al. 2018), but rarely among more distantly related species. Ignatov et al. (2019) review the question how remote hybridization can be in bryophytes.

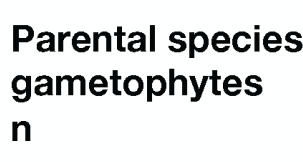

Hybrid sporophyte
(F1)
2n

\section{Recombinant gametophytes (F2) \\ n}

Sporophytes
(F3)
$2 n$

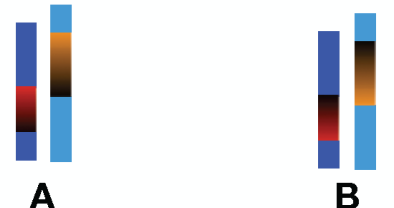

B
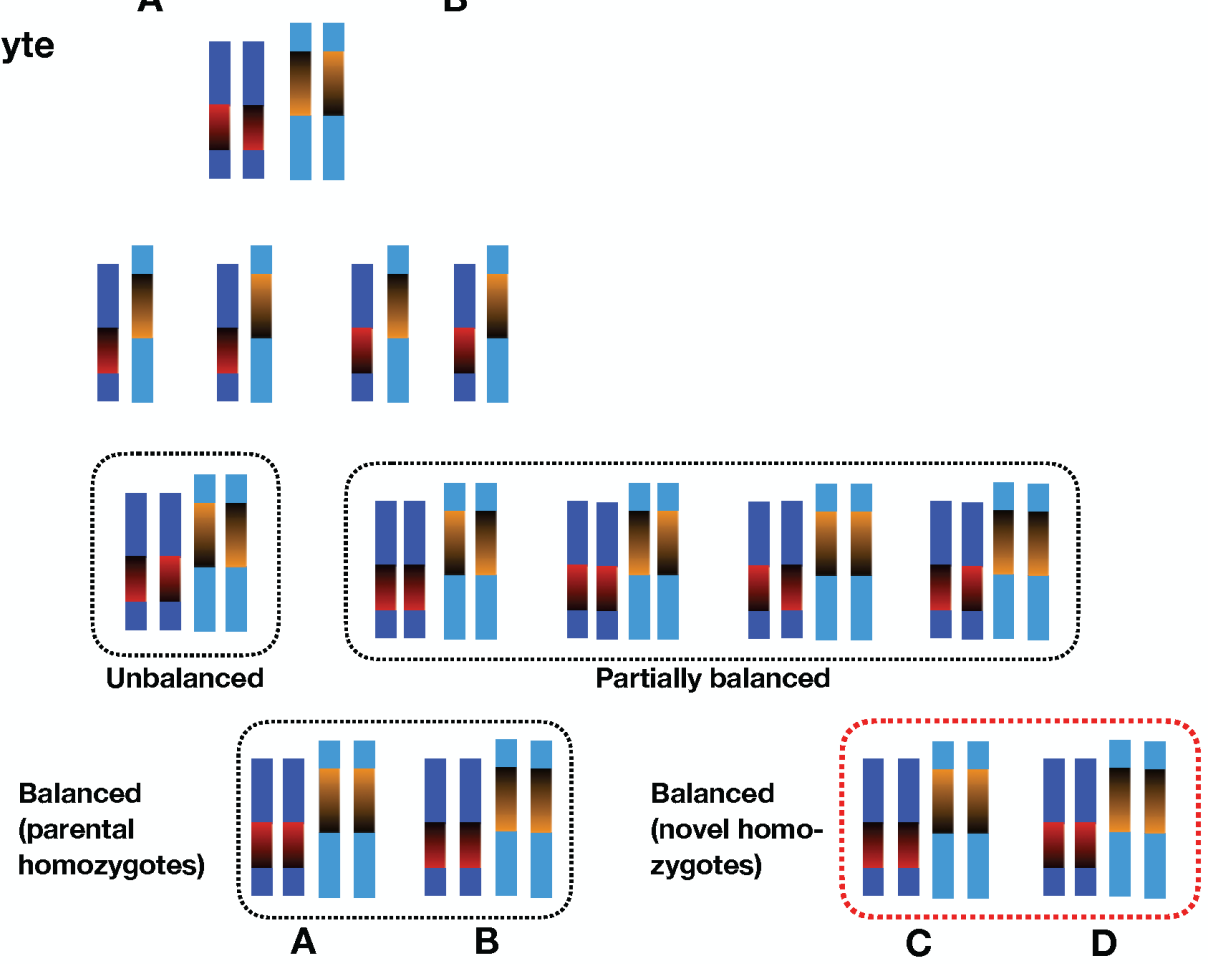

FIGURE 7. Schematic representation of the Grant $(1975,1981)$ model of "recombinational speciation" adopted for bryophytes. Note that gametophyte generations are haploid (n) and sporophyte generations diploid (sn). The parental species (A and B) differ by having two chromosomal inversions (red and orange chromosomal blocks; inversions indicated by inverted shading). Hybridization result in F1 sporophytes that are heterozygous for both the inversions and thus expected to have low fertility. Mating among the F2 recombinant spores can give rise to partially balanced genotypes (homozygous for one inversion; four examples illustrated) in the F3 sporophyte generation, re-establishment of the F1 genotype or the parental genotypes ( $\mathrm{A}$ and $\mathrm{B}$; homozygous for both inversions) as well as two novel balanced genotypes (C and D; homozygous for both inversions). Such a novel balanced genotype is expected to produce viable progeny that shows higher interfertility with other hybrid progeny with the same novel homozygotes as compared to if it would have been back-crossed to the parental species.

\section{New perspectives on hybrid formation in bryophytes after the advent of molecular tools}

Isolation mechanisms can be subdivided into prezygotic and postzygotic mechanisms (before and after fertilization). Spatial isolation is probably the major prezygotic barrier acting against hybridization in bryophytes. This phenomenon is pronounced compared to most vascular plant by short fertilization distances in bryophytes (Natcheva \& Cronberg 2004). Spatial and/or ecological separation may therefore prevent hybridization throughout most of overlapping distributions areas, unless intermediate habitats exist. This is illustrated by Homalothecium lutescens and $\mathrm{H}$. sericeum which are normally ecologically separated, growing on soil and on tree trunks or stone walls, respectively, but found 
to be extensively hybridizing when growing in mixed populations in regionally occurring intermediate habitats on the island of Öland, Sweden (Sawangproh et al. 2020a,b). Adding to this, the two species of Homalothecium are nannandric, meaning that male spores germinating on female shoots develop into minute but sexually active dwarf males which can readily fertilize the female. Rosengren and Cronberg (2015) demonstrated experimentally that females of $H$. lutescens could prevent spore germination of an unrelated species (Isothecium alepecuroides) but spores of $H$. sericeum germinated equally well as the $H$. lutescens spores and developed into dwarf males. This discrimination failure between related species expose an obvious mechanism for hybridization in nannandric species, as it reduces the spatial isolation barrier in mixed or adjacent populations. Nannandry is a widespread phenomen among both acrocarpous and pleurocarpous mosses so the question raises to what extent females can discriminate between native and alien spores in other groups.

Partial or full postzygotic reproductive isolation among allopatric taxa in bryophytes have been demonstrated in crossing experiments (Allen 1937; Burgeff 1943, Proskauer 1969; Proctor 1972; McDaniel et al. 2008). It is not known to what extent reproductive isolation in bryophytes depends on chromosomal or other structural rearrangements at genomic level, incompatibility between the nuclear genome and a foreign chloroplast (or mitochondrium) or some kind of "speciation genes" (related to a reinforcement process). Burgeff (1943) made reciprocal crossings involving the three taxa in the Marchantia polymorpha complex, with varying degrees of reproductive isolation, in particular he observed strikingly different hybrid fertility in reciprocal crosses between subspecies polymorpha and montivagans, suggesting an influence of sex chromosomes or maternally inherited chloroplast or mitochondrial genomes.

The question how polyploids arise in bryophytes have been discussed for a long time. Polyploid hybrids evolve in bryophytes by 1) syndiploidy-doubling of the gametic chromosome number by fusion of daughter cell nuclei in the capsules or diplospory - the production of unreduced spores (Flatberg et al. 2006), by 2) apospory - the regeneration of diploid gametophytes from immature sporophyte tissues (e.g., Anderson, 1980; Shaw 2009) and possibly by 3) endopolyploidy -DNA replication in hybrid spores without nuclear or cell division. The latter is widespread in mosses but rare in liverworts (Bainard \& Newmaster 2010) and a rather recent finding, observed through flow cytometry. Since bryophyte tissue is totipotent (Lal, 1984), any cell can form a new individual, endoploid cells (if disrupted from the normal haploid cells) could possibly form autopolyploid gametophytes. In the case of endopolyploidy, both parental species must have undergone endopolyploid duplication and subsequently hybridized to acquire a progeny that could be interpreted as allopolyploid. In contrast, allopolyploidy is aquired directly if the sporophyte undergoing syndiploidy or apospory is of hybrid origin.

Allopolyploid individuals are believed to rarely introgress with their parental taxa because of differences in ploidy levels (Petit et al. 1999), but several exceptions have been found in Sphagnum. Modern molecular and cytological methods have made it possible to trace secondary hybridization and polyploidization of allopolyploids giving rise to allotriploids, auto-allotriploids and double allopolyploids and to disentangle the various involved parental genomes. Most of these reports have emanated from molecular analyses of herbarium specimens, but the first observation came from a wild population with hybrid sporophytes carried on Sphagnum girgensohnii (maternal parent), apparently fertilized by allopolyploid $S$. russowii (paternal parent), which in turn is a hybrid between $S$. girgensohnii and $S$. rubellum (Flatberg et al. 2006). The genome in the sporophyte was thus $1 \times$ rubellum and $2 \times$ girgensohnii and the triploid was transmitted through syndiploidy or diplospory to the spores, of which $5 \%$ were viable. The resulting gametophytes matched spontaneous gametophytes in the population. This observation was soon followed by several reports of allotriploid and double allopolyploid species (having three and four separate genomes, respectively) by Karlin et al. (2009, 2013, 2014), Karlin (2014) and Kyrkjeeide et al. (2019). These separate genomes originated from close relatives but sometimes also from parental species representing different subgenera of peatmosses.

Grant $(1975,1981)$ proposed the two models for speciation by homoploid hybridization: 1$)$ "The recombinational speciation model", that the two parental species with the same chromosome number differ by two or more chromosomal rearrangements. Due to the chromosomal rearrangements, some F2 progeny with novel homozygotes shows higher interfertility with other hybrid progeny with the same novel homozygotes than when back-crossed to the parental species (Rieseberg 1997). This model might apply also to bryophytes although the sporophytes are comparable to the $\mathrm{F} 1$ generation and the recombinant spores to the F2 generation, meaning that the novel homozygotes should turn up in the second generation of sporophytes (Fig. 7).

2) "The transgressive segregation model", that new combinations of parental alleles may generate hybrids that can survive in new ecological niches unavailable to either parent (Vicente \& Tanksley 1993). Currently, only few cases of speciation by homoploid hybridization have been pointed out for bryophytes, so it is an open question to what extent and under what circumstances these models are realized.

In molecular studies, recombinant bryophyte gametophytes have been proved to display not only asymmetrical 
phenotypic expression but also asymmetrical genomic contribution from the two parental species (Cronberg 1989; Shaw 1998; Cronberg \& Natcheva 2002, Sawangproh et al. 2020a,b). Asymmetrical parental genome could reflect differential levels of fitness of recombinant offspring or secondary back-crossing of hybrid offspring to one of the parental species (Shaw 2009). From what we know from sowing experiments (Flatberg 2006, Natcheva \& Cronberg 2007b), recombinant spores from hybrid sporophytes showed low viability but not complete sterility, and the few viable spores displayed a quite skew inheritance of parental genomes (Natcheva \& Cronberg 2007b; Sawangproh et al. 2020a). The interpretation of skew inheritance was that among the many thousand meiosis events taking place in a sporophyte some may by pure stochasticity have inherited a major part of the genome from one parent, a situation where hybridization results in immediate introgression in the next gametophyte generation rather than hybrids with intermediate expression of traits. The recombinant sporelings had maternally inherited chloroplasts in combination with almost complete paternal dominance of the nuclear genome (Natcheva \& Cronberg 1997a) - the process appears to mimic what is known as chloroplast capture in vascular plants. From what we know today, homoploid hybridization in bryophytes may involve transfer of only few genes between the genomic backgrounds, rather than complete mixing. Sawangproh et al. (2020a,b) found a few sporophytes and gametophytes with strongly admixed genomes in a hybrid zone of Homalothecium lutescens and H. sericeum, but a majority of sporophytes and recombinant gametophytes were only mildly admixed, possibly as a consequence of extensive back-crossing. Similarly, when comparing whole autosomal genomes from 12 individuals belonging to the three taxa of the Marchantia polymorpha-complex, Linde et al. (2020) observed two individuals from separate sites in which small parts on a single chromosome was transferred from one taxon to the other, suggesting limited introgression. At both sites the involved taxa occurred together in sympatry.

\section{Could hybridization explain poor consensus in phylogenetic studies of bryophytes?}

Incongruence between morphology and genomic markers may suggest horizontal gene transfer through interspecific hybridization. For example, some individuals of peat mosses in mixed populations of Sphagnum capillifolium with $S$. rubellum (Cronberg 1989) and S. capillifolium with S. quinquefarium (Cronberg \& Natcheva 2002) were identified as one species by isozyme markers but were identified as the other species by the morphological expression of the gametophytes. Apparently, hybrid progeny expresses a high degree of variability in morphological expression not only in the characters of gametophytes but also in other life stages such as sporophytes and spores (Natcheva \& Cronberg 2004; Sawangproh et al. 2020a,b). Hegarty \& Hiscock (2005) addressed that hybrid speciation may occur repeatedly at different times and at different geographical locations, and, furthermore, backcrossing to either parent or to a related taxon may occur regionally. Consequently, regional morphological differences among hybrids may sometimes lead them to be recognized under different names by different authors.

Observations of cytoplastic introgression and incongruences between rDNA and cpDNA sequences in phylogenetic analyses of vascular plants have been put forward as evidence for past hybridization and historic introgression (Sytsma 1990; Rieseberg 1991; Rieseberg et al. 1996). Phylogenetic incongruence of nuclear and chloroplast DNA sequences supported the hypothesis of hybridization among widely divergent (intersectional) taxa of peat mosses (Shaw \& Goffinet 2000), which partially explains the historic problems to reach a consensus on the taxonomy of the genus Sphagnum (Shaw \& Goffinet 2000). Hernández-Maqueda et al. (2008) found sectional placement of most species in family Grimmiaceae to be congruent based on plastid DNA. However, some species seemingly combine nuclear sequences of one section with chloroplast sequences of another. Similarly, Heinrichs et al. (2011) observed phylogenetic incongruence between chloroplast and nuclear sequences for the leafy liverwort species Porella platyphylloidea, which possibly originated by ancient hybridization between P. cordaeana and P. platyphylla. Werner et al. (2014), Hedenäs (2015), Köckinger \& Hedenäs (2017) found incongruences between nuclear and two chloroplast genes in Tortella, indicating that hybridization is widespread in this acrocarpous moss genus. For example, haplotype networks displayed significant reticulation in a study of the classic hybrid taxon Tortella rigens and its related species, suggesting local backcrossing to the putative parental species T. inclinata and T. fragilis as well as to T. tortuosa. Furthermore, sporophytes were observed on T. rigens, with morphological affinities to T. inclinata and T. tortuosa, which are likely fathers because males are lacking in T. rigens.

When studying closely related taxa it is often difficult or even impossible to differentiate between gene transfer by hybridization and retention of ancient polymorphisms (incomplete lineage sorting). Comparison across whole genomes is now possible and less arbitrary than studies based on occasional genes, but this wealth of data does not automatically 
make it easier to detect hybridization. In a whole genome comparison between the three taxa in the Marchantia polymorpha-complex (including subspecies polymorpha, montivagans and ruderalis) with $M$. paleacea as outgroup all three possible phylogenetic topologies were richly represented among sequences across the genomes (Linde et al. 2020) although concensus analyses singled out montivagans as the earliest diverging branch. Statistical tests did not reveal any signature of hybridization, but it turned out that chromosome 2 of montivagans was more diverged than any other part of the genomes. This could only happen if it was captured by hybridization from a more divergent unknown taxon or if the rest of the chromosomes had converged by hybridization. The second hypothesis was favoured because chromosome 2 of montivagans displayed a higher degree of structural rearrangements, apparently protecting it from intermittent or ongoing hybridization. It is well known from other organisms that genomic regions show differential porosity to gene transfer during hybridization (Harrison \& Larson 2014). The failure of the statistical tests to detect hybridization in this case may be explained if many hybridization events have taken place, each involving only a small part of the genome.

\section{Conclusions and perspectives for future study}

Historically, studies of hybridization in bryophytes were based on observations of gross morphology or chromosomal characteristics of hybrid progeny. More or less intermediate morphological markers and mismatched types of capsules in case of polysetous gametophytes were used for preliminary identification of putative cases of hybridization. A major limitation of morphological or chromosomal traits is the fact that closely related taxa often do not show distinct morphological differences, or the differences are obscured by phenological plasticity (Natcheva \& Cronberg 2004; Maki \& Murata 2001). Therefore, it is evident that recently developed more powerful molecular tools and cytological methods are useful to trace past hybridization and reveal its importance for speciation and differentiation.

This review summarizes a growing body of evidence for interspecific hybridization in bryophytes, both synthesized in vitro and observed in wild populations. The available data indicates that hybridization is important for adaptation and speciation. There is still a large unexploited potential to further study details of hybridization processes and the hitherto gathered data is strongly focused on few groups of bryophytes. In Sphagnum mosses, enough data has accumulated to make it possible to search for patterns underlying evolutionary processes. Accordingly, a review compiled from more than 50 Sphagnum hybridization records by Meleshko et al. (2018) showed that homoploid hybridization takes place among closely related species, whereas allopolyploidy potentially involve more distantly related parental species. Their meta-analysis also suggests some traits that are associated with hybridization in Sphagnum, such as monoicy/ polyoicy, high sporulation frequency, small spores, and propensity to grow in poor habitats.

In comparison to organisms with a dominant diploid generation, bryophytes have been expected to accumulate comparatively little adaptive genetic variation, because mutations, effecting a change in what is apparently the only one copy of a particular allele of genes, must be beneficial or at least not lethal. Thus, Newton (1988) predicted the accumulation of such variation in haploid gametophytes to be slow. Combination of genomes in allopolyploids and transfer of adaptive genes between lineages through homoploid polyploidization could compensate for low mutation rate by transfer of adaptive genes to new genomic backgrounds. Until now there are few studies that have assessed the adaptive value of such gene transfer and for most cases of homoploid hybridization we do not even know if the recombinants are able to transmit such genes to the next generation, to what extent back-crossing takes place or if populations behave as true hybrid zones. Similarly, we know little about infraspecific variability in allopolyploids (or autopolyploids) and if allopolyploidy expands or changes the fundamental and/or realized niches relative to the paternal species.

DNA fingerprint methods such as RFLPs, ISSRs and microsatellites are valuable markers for recently diverged bryophytes (Vanderpoorten \& Shaw 2010), but Schmickl et al. (2017) suggested that future work should focus on population genomic studies that can provide detailed insights into the genetic basis of adaptive divergence. With an increasing genome-wide view of the divergence landscape, population genomic studies can overcome key limitations of previous approaches. For example, they can detect polygenic adaptation provided markers are dense and they can leverage sufficient resolution and statistical power to detect non-random patterns of introgression (Schmickl et al. 2017). The advent of high-throughput sequencing and phylogenomic tests/softwares such as Phylo-Net (network and tree methods), D statistics or ABBA-BABA statistics (detection SNP window-based or genome-wide evidence of shared alleles in a four-taxon case), and HybridCheck (detection of introgressed genomic blocks and visualization of the heterogeneous, mosaic-like genome structure and dating of introgressed blocks) reveals hybridization and introgression 
events at genomic and demographic levels (reviewed in Schmickl et al. 2017; Linde et al. 2020). Although it is now possible to search for signs of hybridization across whole genomes it is still challenging to differentiate between gene transfer by hybridization and incomplete lineage sorting, especially if multiple hybridization events have taken place, each involving transfer of only a small part of the genome and/or if extensive back-crossing against one parent has taken place. For this reason, genomic studies should be complemented by populations level studies of putatively hybridizing parental species, comparing allopatric and sympatric populations.

\section{Acknowledgements}

This study was partially supported by grants from Mahidol University's Academic Development Scholarship.

\section{References}

Abbott, R., Albach, D., Ansell, S., Arntzen, J.W., Baird, S.J.E., Bierne, N., Boughman, J., Brelsford, A., Buerkle, C.A., Buggs, R., Butlin, R.K., Dieckmann, U., Eroukhmanoff, F., Grill, A., Cahan, S.H., Hermansen, J.S., Hewitt, G., Hudson, A.G., Jiggins, C., Jones, J., Keller, B., Marczewski, T., Mallet, J., Martinez-Rodriguez, P., Möst, M., Mullen, S., Nichols, R., Nolte, A.W., Parisod, C., Pfennig, K., Rice, A.M., Ritchie, M.G., Seifert, B., Smadja, C.M., Stelkens, R., Szymura, J.M., Väinöla, R., Wolf, J.B.W. \& Zinner, D. (2013) Hybridization and speciation. Journal of Evolutionary Biology 26: 229-246. https://doi.org/10.1111/j.1420-9101.2012.02599.x

Abderrahman, S. (1998) DNA content of two cytotypes of Funaria hygrometrica. Korean Journal of Genetics 20: $103-108$.

Abderrahman, S.A. (2004) Nuclear DNA content of haploid and diploid Physcomitruim pyriforme using DAR staining. Korean Journal of Genetics 26: 245-250.

Allen, C.E. (1930) Inheritance in a hepatic. Science 71: 197-204. https://doi.org/10.1126/science.71.1834.197

Allen, C.E. (1935) The genetics of bryophytes. The Botanical Review 1: 269-291. https://doi.org/10.1007/BF02869756

Allen, C.E. (1937) Fertility and compatibility in Sphaerocarpos. Cytologia. Fujii Jubilee 1937: 494-501. https://doi.org/10.1508/cytologia.FujiiJubilaei.494

Allen, C.E. (1945) The genetics of bryophytes II. The Botanical Review 11: 260-287. https://doi.org/10.1007/BF02861195

Allendorf, F.W., Leary, R.F., Spruell, P. \& Wenburg, J.K. (2001) The problems with hybrids: setting conservation guidelines. Trends in Ecology and Evolution 16: 613-622. https://doi.org/10.1016/S0169-5347(01)02290-X

Anderson, E. (1948) Hybridization of the habitat. Evolution 2: 1-9. https://doi.org/10.1111/j.1558-5646.1948.tb02726.x

Anderson, E. \& Stebbins, G.L. (1954) Hybridization as an evolutionary stimulus. Evolution 8: 378-388. https://doi.org/10.2307/2405784

Anderson, L.E. (1963) Modern species concepts: mosses. The Bryologist 46: 47-66.

Anderson, L.E. (1980) Cytology and reproductive biology of mosses. In: Taylor, R.J. \& Levontin, L.E. (Eds.) The mosses of North America. California Academy of Sciences, San Francisco, California, pp. 37-76.

Anderson, L.E. \& Lemmon, B.E. (1972) Cytological Studies of Natural Intergeneric Hybrids and Their Parental Species in the Moss Genera, Astomum and Weissia. Annals of the Missouri Botanical Garden 59: 382-416. https://doi.org/10.2307/2395151

Andrews, A.L. (1918) Bryological notes IV: A new hybrid in Physcomitrium. Torreya 18: 52-54.

Andrews, A.L. (1922) Hymenostomum in North America. II. The case of Astomum sullivantii. The Bryologist 25: 66-71. https://doi.org/10.2307/3238657

Andrews, A.L. (1960) Taxonomic notes. XV. The reciprocal hybrid of Ditrichum-Pleuridium. The Bryologist 63: 179-181. https://doi.org/10.2307/3241054

Andrews, A.L. \& Hermann, F.J. (1959) A natural hybrid in the Ditrichaceae. The Bryologist 62: 119-122. https://doi.org/10.2307/3240030

Arnold, S.J., Avise, J.C., Ballou, J., Eldridge, J. \& Flemming, D. (1991) Genetic management considerations for threatened species with 
a detailed analysis of the Florida panther (Felis concolor coryi). Washington, DC: USFWS.

Bainard, J.D. \& Newmaster, S.G. (2010) Endopolyploidy in bryophytes: Widespread in mosses and absent in liverworts. Journal of Botany 2010: 1-7.

https://doi.org/10.1155/2010/316356

Barbulescu, E.V.I., Patzak, S.D.F., Feldberg, K., Schäfer-Verwimp, A., Rycroft, D.S., Renner, M.A.M. \& Heinrichs, J. (2017) Allopolyploid origin of the leafy liverwort Plagiochila britannica (Plagiochilaceae). Botanical Journal of the Linnean Society 183: 250-259. https://doi.org/10.1093/botlinnean/bow005

Bell, N.E. \& Hyvönen, J. (2010) Phylogeny of the moss class Polytrichopsida (BRYOPHYTA): Generic-level structure and incongruent gene trees. Molecular Phylogenetics and Evolution 55: 381-398. https://doi.org/10.1016/j.ympev.2010.02.004

Bhatia, S., Negi, M.L. \& Lakshmikumaran, M. (1996) Structural analysis of the rDNA intergenic space of Brassica nigra: evolutionary divergence of the spacers of the three diploid Brassica species. Journal of Molecular Evolution 43: 460-468. https://doi.org/10.1007/BF02337518

Bischler, H. \& Boisselier-Dubayle, M.C. (1993) Variation in a polyploid, dioicous liverwort, Marchantia globosa. American Journal of Botany 80: 953-958. https://doi.org/10.1002/j.1537-2197.1993.tb15317.x

Blackstock, N. \& Ashton, P.A. (2010) Genetic markers and morphometric analysis reveal past hybridization and introgression in putative Carex flava L. s.str. (Cyperaceae) hybrid populations. Plant Systematics and Evolution 287: 37-47. https://doi.org/10.1007/s00606-010-0287-0

Boisselier-Dubayle, M.C. \& Bischler, H. (1998) Allopolyploidy in the thalloid liverwort Corsinia (Marchantiales). Botanica Acta 111: 490-496. https://doi.org/10.1111/j.1438-8677.1998.tb00737.x

Boisselier-Dubayle, M.C. \& Bischler, H. (1999) Genetic relationships between haploid and triploid Targionia (Targioniaceae, Hepaticae). International Journal of Plant Sciences 160: 1163-1169. https://doi.org/10.1086/314199

Boisselier-Dubayle, M.C., Lambourdiere, J. \& Bischler, H. (1998a) The leafy liverwort Porella baueri (Porellaceae) is an allopolyploid. Plant Systematics and Evolution 210: 175-197. https://doi.org/10.1007/BF00985667

Boisselier-Dubayle, M.C., Lambourdiere, J. \& Bischler, H. (1998b) Taxa delimitation in Reboulia investigated with morphological, cytological, and isozyme markers. The Bryologist 101: 61-69. https://doi.org/10.2307/3244074

Bremer, B. (1981) A Taxonomic Revision of Schistidium (Grimmiaceae, Bryophyta) 3. Lindbergia 7: 73-90.

Buczkowska, K., Odrzykoski, I.J. \& Chudzinska, E. (2004) Delimitation of some European species of Calypogeia Raddi (Jungermanniales, Hepaticae) based on cytological characters and multienzyme phenotype. Nova Hedwigia 78: 147-163. https://doi.org/10.1127/0029-5035/2004/0078-0147

Buczkowska, K., Sawicki, J., Szczecińska, M., Klama, H. \& Bączkiewicz, A. (2012) Allopolyploid speciation of Calypogeia sphagnicola (Jungermanniopsida, Calypogeiaceae) based on isozyme and DNA markers. Plant Systematics and Evolution 298: 549-560. https://doi.org/10.1007/s00606-011-0565-5

Buerkle, C.A., Morris, R.J., Asmussen, M.A. \& Rieseberg, L.H. (2000) The likelihood of homoploid hybrid speciation. Heridity 84: $441-451$ https://doi.org/10.1046/j.1365-2540.2000.00680.x

Burgeff, H. (1943) Genetische Studien an Marchantia. Gustav Fischer, Jena, 296 pp.

Burke, J.M. \& Arnold, M.L. (2001) Genetics and the fitness of hybrids. Annual Review of Genetics 35: 31-52. https://doi.org/10.1146/annurev.genet.35.102401.085719

Buryová, B. (2004) Genetic variation in two closely related species of Philonotis based on isozyme. The Bryologist 107: $316-327$. https://doi.org/10.1639/0007-2745(2004)107[0316:GVITCR]2.0.CO;2

Callaghan, D.A., Masson, J. \& During, H. (2020a) Physcomitrium $\times$ stevensoni D.A. Callaghan $($ Physcomitrium patens $\times$ P. eurystomum) (Funariaceae, Bryophyta), a new name for a rarely recorded hybrid moss. Journal of Bryology 42: 192-194. https://doi.org/10.1080/03736687.2020.1725325

Callaghan, D.A., Medina, R., Masson, J. \& During, H.J. (2020) Population status and ecology of the episodic moss Physcomitrium eurystomum Sendtn. in Britain. Journal of Brylogy 42 (3): 246-257. https://doi.org/10.1080/03736687.2020.1743562

Campbell, E.O. (1971) Problems in the origin and classification of bryophytes with particular reference to liverworts. New Zealand Journal of Botany 9: 678-688. 
https://doi.org/10.1080/0028825X.1971.10430230

Carrión, J.S., Ros, R.M. \& Guerra, J. (1993) Spore morphology in Pottia starckeana (Hedw.) C. Müll. (Pottiaceae, Musci) and its closest species. Nova Hedwigia 56: 89-112.

Chudzinska, E. \& Odrzykoski, I.J. (2010) Fast identification method for an allopolyploid liverwort Pellia borealis Lorbeer (Hepaticae, Metzgeriales). Cryptogamie Bryologie 31: 207-215.

Clarke, G.C.S. (1979) Spore morphology and bryophyte systematics. In: Clarke, G.C.S. \& Duckett, J.G. (Eds.) Bryophyte Systematics. Academic Press, London, pp. 231-250.

Clarke, S.M., Henry, H.M., Dodds, K.G., Jowett, T.W.D., Manley, T.R., Anderson, R.M. \& Mcewan, J.C. (2014) A High Troughput Single Nucleotide Polymorphism Multiplex Assay for Parentage Assignment in New Zealand Sheep. PLoS ONE 9: e93392. https://doi.org/10.1371/journal.pone.0093392

Cox, C.J., Goffinet, B., Shaw, A.J. \& Boles, S.B. (2004) Phylogenetic relationships among the mosses based on heterogeneous Bayesian analysis of multiple genes from multiple genomic compartments. Systematic Botany 29: 234-250.

https://doi.org/10.1600/036364404774195458

Coyne, J.A. \& Orr, H.A. (2004) Speciation. Sunderland, Massachusetts, Sinauer Associates, 545 pp.

Cronberg, N. (1989) Patterns of variation in morphological characters and isoenzymes in populations of Sphagnum capillifolium (Ehrh.) Hedw. and S. rubellum Wils. from two bogs in southern Sweden. Journal of Bryology 15: 683-696.

https://doi.org/10.1179/jbr.1989.15.4.683

Cronberg, N. (1992) Reproductive Biology of Sphagnum. Lindbergia 17: 69-82.

Cronberg, N. (1996) Isozyme evidence of relationships within Sphagnum sect. Acutifolia (Sphagnaceae, Bryophyta). Plant Systematics and Evolution 203: 41-64. https://doi.org/10.1007/BF00985236

Cronberg, N. \& Natcheva, R. (2002) Hybridization between the peat mosses, Sphagnum capillifolium and S. quinquefarium (Sphagnaceae, Bryophyta) as inferred by morphological characters and isozyme markers. Plant Systematics and Evolution 234: 53-70. https://doi.org/10.1007/s00606-002-0196-y

Crundwell, A.C. \& Nyholm, E. (1964) The European species of the Bryum erythrocarpum complex. Transactions of the British Bryological Society 4: 597-637.

https://doi.org/10.1179/006813864804812128

Crundwell, A.C. \& Nyholm, E. (1974) Funaria muhlenbergii and Related European Species. Lindbergia 2: $222-229$.

Crundwell, A.C. \& Nyholm, E. (1977) Dicranella howei Ren. \& Card. and Its Relationship to D. varia (Hedw.) Schimp. Lindbergia 4: 35-38.

Delgadillo, M.C. (1989) Astomiopsis $\times$ altivallis (Musci: Ditrichaceae), a putative interspecific hybrid in Mexico. The Bryologist 92: $225-227$. https://doi.org/10.2307/3243950

Derda, G.S. \& Wyatt, R. (2000) Isozyme evidence regarding the origins of three allopolyploid species of Polytrichastrum (Polytrichaceae, Bryophyta). Plant Systematics and Evolution 220: 37-53. https://doi.org/10.1007/BF00985369

Dobzhansky, T. (1937) Genetics and the origin of species. Columbia University Press, New York.

Doyle, W.T. (1960) Maternal inheritance and interspecific hybrids of the liverwort Sphaerocarpos. Nature 187: 429-430. https://doi.org/10.1038/187429a0

Ellstrand, N.C. \& Elam, D.R. (1993) Population genetic consequences of small population size: implications for plant conservation. Annual Review of Ecology and Systematics 24: 217-242. https://doi.org/10.1146/annurev.es.24.110193.001245

Fiedorow, P., Odrzykoski, I., Szweykowski, J. \& Szweykowska-Kulinska, Z. (2001) Phylogeny of the European species of the genus Pellia (Hepaticae; Metzgeriales) based on the molecular data from nuclear tRNA(CAA)(Leu) intergenic sequences. Gene 262: 309-315. https://doi.org/10.1016/S0378-1119(00)00523-0

Flatberg, K.I. (1988) Sphagnum angustifolium (Russ.) C. Jens. $\times$ S. pulchrum (Braithw.) Warnst., a gametophyte hybrid. Lindbergia 14: 4-7.

Flatberg, K.I. (2005) Taxonomy, Geography and Possible Origin of Sphagnum inexspectatum (Sect. Subsecunda) sp. nov. Lindbergia 30: 59-78.

Flatberg, K.I. \& Frisvoll, A.A. (1984) Sphagnum arcticum sp. nov. The Bryologist 87: 143-148. https://doi.org/10.2307/3243120

Flatberg, K.I., Thingsgaard, K. \& Såstad, S.M. (2006) Interploidal gene flow and introgression in bryophytes: Sphagnum girgensohnii $\times$ Sphagnum russowii, a case of spontaneous neotriploidy. Journal of Bryology 28: 27-37.

https://doi.org/10.1179/174328206X90459 
Frahm, J. \& Ho, B. (2010) Discovery of a natural hybrid between Bruchia vogesiaca Schwagr. and Trematodon ambiguus (Hedw.) Hornsch (Musci, Bruchiaceae). Cryptogamie Bryologie 31: 95-99.

Freeland, J.R., Kirk, H. \& Petersen, S.D. (2011) Molecular Ecology. $2^{\text {nd }}$ ed. Wiley-Blackwell. 464 pp. https://doi.org/10.1002/9780470979365

Frisvoll, A.A. (1978) The genus Tetraplodon in Norway, a taxonomic revision. Lindbergia 4: 225-246.

Fritsch, R. (1982) Index to plant chromosome numbers-Bryophyta. Regnum Vegetabile 108: 1-140.

Gallego, M.T., Cano, M.J., Ros, R.M. \& Guerra, J. (2002) New Taxonomic Data on a Circum-Tethyan Group of Syntrichia (Pottiaceae, Bryophyta): the S. caninervis Complex. Systematic Botany 27: 643-653.

Gibson, D.J. (2015) Methods in comparative plant population ecology. $2^{\text {nd }}$ ed. Oxford University Press, $320 \mathrm{pp}$.

Grant, V. (1975) Genetics of flowering plants. $2^{\text {nd }}$ edition. Columbia University Press, New York, USA.

Grant, V. (1981) Plant Speciation. New York: Columbia University Press. New York, USA, 563 pp.

Gross, B.L. \& Rieseberg, L.H. (2005) The ecological genetics of homoploid hybrid speciation. Journal of Heredity 96: 241-252. https://doi.org/10.1093/jhered/esi026

Guerra, J., Ros, R.M. \& Cano, M.J. (1994) Pterygoneurum subsessile (Brid.) Jur. var. kieneri Hab. (Musci, Pottiaceae), a putative hybrid. Nova Hedwigia 58: 507-510.

Györffy, I. (1907) Ueber die vergleichenden anatomischen Verhältnisse von Physcomitrella patens (Hedw.) Br. et Sch., Physcomitrium pyriforme (L.) Brid., Physcomitrium sphaericum (Ludw.) Brid., und Physcomitrella Hampei Limpr. [Physcomitrella patens (Hedw.) $\times$ Physcomitrium sphaericum (Ludw.), resp.: Physcomitrella patens (Hedw.) $\times$ Physcomitrium pyriforme (L.)]. Hedwigia 47: 1-59.

Harrison, R.G. \& Larson, E.L. (2014) Hybridization, introgression, and the nature of species boundaries. Journal of Heredity 105: 795809. https://doi.org/10.1093/jhered/esu033

Hedderson, T.A. (1986) A naturally occurring moss hybrid between Orthotrichum gymnostomum and O. obtusifolium from Newfoundland, Canada. The Bryologist 89: 165-167. https://doi.org/10.2307/3242759

Hedenäs, L. (2015) Tortella rigens (Bryophyta, Pottiaceae): relationships, regional variation, and conservation aspects. Plant Systematics and Evolution 301: 1361-1375. https://doi.org/10.1007/s00606-014-1159-9

Hegarty, M.J. \& Hiscock, S.J. (2005) Hybrid speciation in plants: new insights from molecular studies. New Phytologist 165: 411-423. https://doi.org/10.1111/j.1469-8137.2004.01253.x

Heinrichs, J., Kreier, H.P., Feldberg, K., Schmidt, A.R., Zhu, R.L., Shaw, B., Shaw, A.J. \& Wissemann, V. (2011) Formalizing morphologically cryptic biological entities: New insights from DNA taxonomy, hybridization, and biogeography in the leafy liverwort Porella platyphylla (Jungermanniopsida, Porellales). American Journal of Botany 98: 1252-1262. https://doi.org/10.3732/ajb.1100115

Hernández-Maqueda, R., Quandt, D. \& Muñoz, J. (2008) Testing reticulation and adaptive convergence in the Grimmiaceae (Bryophyta). Taxon 57: 500-510.

Hofmann, H. (1998) A monograph of the genus Homalothecium (Brachytheciaceae, Musci). Lindbergia 23: 119-159.

Holmen, K. \& Scotter, G.W. (1971) Mosses of the Reindeer Preserve, Northwest Territories, Canada. Lindbergia 1: 34-56.

Hugonnot, V. (2017) Comparative investigations of niche, growth rates and reproduction between the native moss Campylopus pilifer and the invasive C. introflexus. Journal of Bryology 39: 79-84. https://doi.org/10.1080/03736687.2016.1210871

Hylander, K. (1999) Intermediates between the pleurocarpous mosses Dichelyma falcatum (Hedw.) Myr. And D. capillaceum (Dicks.) Myr., possible of hybrid origin. Lindbergia 24: 59-64.

Ignatov, M.S. \& Milyutina, I.A. (2011) Intrafamilial hybridization in mosses? an enigmatic case in the genus Podperaea (Hypnales, Bryophyta). Arctoa 20: 107-118.

https://doi.org/10.15298/arctoa.20.08

Ignatov, M.S., Kuznetsova, O.I. \& Ignatova, E.A. (2019) Hybridization in mosses and how remote it could be. Biology Bulletin Reviews 9: $267-273$ https://doi.org/10.1134/S207908641903006X

Ireland, R. (1987) Scanning electron microscope study of the spores of the North American species of Plagiothecium. Memoirs of the New York Botanical Garden 45: 95-110.

Jankowiak, K., Rybarczyk, A., Wyatt, R., Odrzykoski, I., Pacak, A. \& Szweykowska-Kulinska, Z. (2005) Organellar Inheritance in the Allopolyploid Moss Rhizomnium pseudopunctatum. Taxon 54: 383-388.

https://doi.org/10.2307/25065367

Jankowiak, K. \& Szweykowska-Kulinska, Z. (2004) Organellar inheritance in the allopolyploid liverwort species Porella baueri 
(Porellaceae): Reconstructing historical events using DNA analysis data. In: Goffinet, B., Hollowell, V. \& Magill, R. (Eds.) Molecular Systematics of Bryophytes, Missouri Botanical Garden Press, St Louis, pp. 404-414.

Jankowiak-Siuda, K., Pacak, A., Odrzykoski, I., Wyatt, R. \& Szweykowska-Kulinska, Z. (2008) Organellar inheritance in the allopolyploid moss Plagiomnium curvatulum. Taxon 57: 145-152.

Jin, Y., Liu, S., Yuan, Z., Yang, Y., Tan, S. \& Liu, Z. (2016) Catfish genomic studies: progress and perspectives. In: MacKenzie, S. \& Jentoft, S. (Eds.) Genomics in Aquaculture. Elsevier Inc., pp. 73-104.

https://doi.org/10.1016/B978-0-12-801418-9.00004-4

Karlin, E.F. (2014) Subgenome analysis of two southern hemisphere allotriploid species in Sphagnum (Sphagnaceae). Journal of Bryology 36: $165-179$. https://doi.org/10.1179/1743282014Y.0000000098

Karlin, E.F., Boles, S.B., Ricca, M., Temsch, E., Greilhuber, J. \& Shaw, A.J. (2009) Three-genome mosses: complex double allopolyploid origins for triploid gametophytes in Sphagnum. Molecular Ecology 18: 1439-1454. https://doi.org/10.1111/j.1365-294X.2009.04113.x

Karlin, E.F., Buck, W.R., Seppelt, R.D., Boles, S.B. \& Shaw, A.J. (2013) The double allopolyploid Sphagnum $\times$ falcatulum (Sphagnaceae) in Tierra del Fuego, a Holantarctic perspective. Journal of Bryology 35: 157-172. https://doi.org/10.1179/1743282013Y.0000000066

Karlin, E.F., Gardner, G. P., Lukshis, K., Boles, S. \& Shaw, A.J. (2010) Allopolyploidy in Sphagnum mendocinum and S. papillosum (Sphagnaceae). The Bryologist 113: 114-119. https://doi.org/10.1639/0007-2745-113.1.114

Karlin, E.F. \& Smouse, P. (2017) Allo-allo-triploid Sphagnum $\times$ falcatulum: single individuals contain most of the Holantarctic diversity for ancestrally indicative markers. Annals of Botany 120: 221-231. https://doi.org/10.1093/aob/mcw269

Karlin, E.F., Temsch, E.M., Bizuru, E., Marino, J., Boles, S.B., Devos, N. \& Shaw, A.J. (2014) Invisible in plain sight: recurrent double allopolyploidy in the African Sphagnum × planifolium (Sphagnaceae). The Bryologist 117: 187-201. https://doi.org/10.1639/0007-2745-117.2.187

Khanna, K.R. (1960) Studies in natural hybridization in the genus Weissia. The Bryologist 63: 1-16. https://doi.org/10.2307/3241166

Köckinger, H. \& Hedenäs, L. (2017) A farewell to Tortella bambergeri (Pottiaceae) as understood over the last decades. Journal of Bryology 39: 213-225. https://doi.org/10.1080/03736687.2017.1307313

Košnar, J. \& Koláŕ, F. (2009) A taxonomic study of selected European taxa of the Tortula muralis (Pottiaceae, Musci) complex: variation in morphology and ploidy level. Preslia 81: 399-421.

Košnar, M.J., Miroslava, H., Koláŕ, F., Koutecký, P. \& Kučera, J. (2012) A case study of intragenomic ITS variation in bryophytes: Assessment of gene flow and role of polyploidy in the origin of European taxa of the Tortula muralis (Musci: Pottiaceae) complex. Taxon 61: 709-720. https://doi.org/10.1002/tax.614001

Kugita, M., Kaneko, A., Yamamoto, Y., Takeya, Y., Matsumoto, T. \& Yoshinaga, K. (2003) The complete nucleotide sequence of the hornwort (Anthoceros formosae) chloroplast genome: insight into the earliest land plants. Nucleic Acids Research 31: 716-721. https://doi.org/10.1093/nar/gkg155

Kyrkjeeide, M.O., Hassel, K., Aguero, B., Temsch, E.M., Afonina, O.M., Shaw, A.J., Stenøien, H.K. \& Flatberg, K.I. (2019). Sphagnum $\times$ lydiae, the first allotriploid peatmoss in the northern hemisphere. The Bryologist 122: 38-61. https://doi.org/10.1639/0007-2745-122.1.038

Lal, M. (1984) The Experimental Biology of Bryophytes. Academic Press, London, pp. 97-115.

Levin, D.A., Francisco-Ortega, J. \& Jansen, R.K. (1996) Hybridization and the extinction of rare species. Conservation Biology 10: $10-16$. https://doi.org/10.1046/j.1523-1739.1996.10010010.x

Linde, A-M., Sawangproh, W., Cronberg, N., Szövényi, P. \& Lagercrantz, U. (2020) Evolutionary history of the Marchantia polymorpha complex. Frontiers in Plant Science. https://doi.org/10.3389/fpls.2020.00829

Liu, Y., Moskwa, N.L. \& Goffinet, B. (2012) Development of eight mitochondrial markers for Funariaceae (Musci) and their amplification success in other mosses. American Journal of Botany 99: 62-65. https://doi.org/10.3732/ajb.1100402

Lobachevs'ka, O.V., Demkiv, O.T. \& Ripets'kyi, R.T. (1986) Cytophotometric determination of nuclear DNA in the polyploid complex Tortula muralis Hedw. Ukrayins 'kyi Botanichnyi Zhurnal 43: 23-26. 
Lobachevs'ka, O.V. \& Ulychna, K.O. (1994) Peculiarities of hybrid population of moss Tortula canescens Mont. times T. muralis Hedw. from vicinities of Nikolayev (Lviv district). Ukrayins 'kyi Botanichnyi Zhurnal 51: 84-91.

Lysak, M.A., Fransz, P.F., Ali, H.B.M. \& Schubert, I. (2001) Chromosome painting in Arabidopsis thaliana. Plant Journal 28: 689-697. https://doi.org/10.1046/j.1365-313x.2001.01194.x

Maki, M. \& Murata, J. (2001) Allozyme analysis of the hybrid origin of Arisaema ehimense (Araceae). Heredity 86: 87-93. https://doi.org/10.1046/j.1365-2540.2001.00813.x

Mallet, J. (2007) Hybrid speciation. Nature 446: 279-283. https://doi.org/10.1038/nature05706

Mayr, E. (1942) Systematics and the origin of species. Columbia University Press, New York, 334 pp.

McDaniel, S.F., von Stackelberg, M., Richardt, S., Quatrano, R.S., Reski, R. \& Rensing, S.A. (2010) The speciation history of the Physcomitrium-Physcomitrella species complex. Evolution 64: 217-231. https://doi.org/10.1111/j.1558-5646.2009.00797.x

McDaniel, S.F., Willis, J.H. \& Shaw, A.J. (2007) Linkage map reveals a complex basis for segregation distortion in an interpopulation cross in the moss Ceratodon purpureus. Genetics 176: 2489-2500. https://doi.org/10.1534/genetics.107.075424

McDaniel, S.F., Willis, J.H. \& Shaw, A.J. (2008) The Genetic Basis of Developmental Abnormalities in Interpopulation Hybrids of the Moss Ceratodon purpureus. Genetics 179: 1425-1435. https://doi.org/10.1534/genetics.107.086314

McIntosh, T.T. (1989) Bryophyte Records from the Semiarid Steppe of Northwestern North America, including Four Species New to North America. The Bryologist 92: 356-362. https://doi.org/10.2307/3243404

Meleshko, O., Stenøien, H.K., Speed, J.D.M., Flatberg, K., Kyrkjeeide, M.O. \& Hassel, K. (2018) Is interspecific gene flow and speciation in peatmosses (Sphagnum) constrained by phylogenetic relationship and life-history traits? Lindbergia 41: linbg.01107, 2018. https://doi.org/10.25227/linbg.01107

Natcheva, R. \& Cronberg, N. (2004) What do we know about hybridization among bryophytes in nature? Canadian Journal of Botany 82: $1687-1704$. https://doi.org/10.1139/b04-139

Natcheva, R. \& Cronberg, N. (2007a) Maternal transmission of cytoplasmic DNA in interspecific hybrids of peat mosses, Sphagnum (Bryophyta). Journal of Evolutionary Biology 20: 1613-1616. https://doi.org/10.1111/j.1420-9101.2007.01341.x

Natcheva, R. \& Cronberg, N. (2007b) Recombination and introgression of nuclear and chloroplast genomes between the peat mosses, Sphagnum capillifolium and Sphagnum quinquefarium. Molecular Ecology 16: 811-818. https://doi.org/10.1111/j.1365-294X.2006.03163.x

Newton, M.E. (1983) Cytology of the Hepaticae and Anthocerotae. In: Schuster, R.M. (Ed.) New Manual of Bryology, Vol. 1. The Hattori Botanical Laboratory, Nichinan, p. 1295.

Newton, M.E. (1988) Chromosomes as indicators of bryophyte reproductive performance. Botanical Journal of the Linnean Society 98 : $269-275$. https://doi.org/10.1111/j.1095-8339.1988.tb02430.x

Nickrent, D.L., Parkinson, C.L., Palmer, J.D. \& Duff, R.J. (2000) Multigene Phylogeny of Land Plants with Special Reference to Bryophytes and the Earliest Land Plants. Molecular Biology and Evolution 17: 1885-1895.

https://doi.org/10.1093/oxfordjournals.molbev.a026290

Nicholson, W.E. (1905) Notes on two forms of hybrid Weisia. Revue Bryologique 32: 19-25.

Nicholson, W.E. (1906) Weisia crispa Mitt. $\times$ W. microstoma C.M. Revue Bryologique 33: 1-2.

Nicholson, W.E. (1910) A new hybrid moss. Revue Bryologique 37: 23-24.

Nicholson, W.E. (1931) Hybridity among the bryophytes. Revue Bryologique 4: 138-140.

Nieto-Lugilde, M. (2019) The moss genus Ceratodon: Studies of Evolutionary Biology and Taxonomy in southern Europe. PhD thesis, University of Murcia, Spain.

Nieto-Lugilde, M., Werner, O., McDaniel, S.F. \& Ros-Espín, R.M. (2018) Environmental variation obscures species diversity in southern European populations of the moss genus Ceratodon. Taxon 67: 673-692. https://doi.org/10.12705/674.1

Norrell, T.E., Jones, K.S., Payton, A.C. \& McDaniel, S.F. (2014) Meiotic sex ratio variation in natural populations of Ceratodon purpureus (Ditrichaceae). American Journal of Botany 101: 1572-1576. https://doi.org/10.3732/ajb.1400156

Nyholm, E. (1954) Illustrated Moss Flora of Fennoscandia. II. Musci. Fasc. I. Lund. Gleerup 
Nyholm, E. (1958) Illustrated Moss Flora of Fennoscandia. II. Musci. Fasc. III. Lund. Gleerup.

Odrzykoski, I.J., Chudzińska, E. \& Szweykowski, J. (1996) The hybrid origin of the polyploidy liverwort Pellia borealis. Genetica 98: $75-86$. https://doi.org/10.1007/BF00120221

Orzechowska, M., Karcz, J. \& Małuskyńska, J. (2006) Comparative analysis of the structure of the allopolyploid liverwort Pellia borealis and ancestral taxa. Biodiversity Research and Conservation 1-2: 54-56.

Orzechowska, M., Siwinska, D. \& Maluszynska, J. (2010) Molecular cytogenetic analyses of haploid and allopolyploid Pellia species. Journal of Bryology 32: 113-121. https://doi.org/10.1179/037366810X12578498136075

Pacak, A. \& Szweykowska-Kulinska, Z. (2003) Organellar inheritance in liverworts: An example of Pellia borealis. Journal of Molecular Evolution 56: 11-17. https://doi.org/10.1007/s00239-002-2375-4

Pardo, D.C., Terracciano, S., Giordano, S. \& Spagnuolo, V. (2014) Molecular Markers Based on PCR Methods: A Guideline for Mosses. Cryptogamie, Bryologie 35: 229-246. https://doi.org/10.7872/cryb.v35.iss3.2014.229

Parker, P.G., Snow, A.A., Schug, M.D., Booton, G.C. \& Fuerst, P.A. (1998) What molecules can tell us about populations: choosing and using a molecular marker. Ecology 79: 361-382. https://doi.org/10.2307/176939

Pereira, M.R., Ledent, A., Mardulyn, P., Zartman, C.E. \& Vanderpoorten, A. (2019) Maintenance of genetic and morphological identity in two sibling Syrrhopodon species (Calymperaceae, Bryopsida) despite extensive introgression. Journal of Systematics and Evolution 57: 395-403. https://doi.org/10.1111/jse.12502

Persson, H. (1954) Mosses of Alaska-Yukon. The Bryologist 57: 189-217. https://doi.org/10.2307/3240083

Petit, C., Bretagnolle, F. \& Felber, F. (1999) Evolutionary consequences of diploid-polyploid hybrid zones in wild species. Trends in Ecology \& Evolution 14: 306-311. https://doi.org/10.1016/S0169-5347(99)01608-0

Pettet, A. (1964) Hybrid sporophytes in the Funariaceae. I. hybrid sporophytes on Physcomitrella patens (Hedw.) B. \& S. and Physcomitrium sphaericum (Schkuhr) Brid. In Britain. Transactions of the British Bryological Society 4: 642-648. https://doi.org/10.1179/006813864804812164

Pócs, T., Sabovljevic, M., Puche, F., Moragues, J.G.S., Gimeno, C. \& Kürschner, H. (2004) Crossidium laxefilamentosum Frey \& Kürschner (Bryopsida: Pottiaceae), new to Europe and to North Africa. Journal of Bryology 26: 113-124. https://doi.org/10.1179/037366804225021074

Proctor, V.W. (1972) The genus Riella in North and South America: Distribution, culture and reproductive isolation. The Bryologist 75: $281-289$ https://doi.org/10.2307/3241465

Proskauer, J. (1969) Studies on Anthocerotales. VIII. Phytomorphology 19: 52-66.

Reese, W.D. \& Lemmon, B.E. (1965) A natural hybrid between Weissia and Astomum and notes on the nomenclature of the North American species of Astomum. The Bryologist 68: 277-283. https://doi.org/10.2307/3240597

Rhymer, J.M. \& Simberloff, D. (1996) Extinction by hybridization and introgression. Annual Review of Ecology and Systematics 27: 83-109. https://doi.org/10.1146/annurev.ecolsys.27.1.83

Ricca, M., Beecher, F.W., Boles, S.B., Temsch, E., Greilhuber, J., Karlin, E.F. \& Shaw, A.J. (2008) Cytotype variation and allopolyploidy in North American species of the Sphagnum subsecundum complex. American Journal of Botany 95: 1606-1620. https://doi.org/10.3732/ajb.0800148

Ricca, M. \& Shaw, A.J. (2010) Allopolyploidy and homoploid hybridization in the Sphagnum subsecundum complex (Sphagnaceae: Bryophyta). Biological Journal of the Linnean Society 99: 135-151. https://doi.org/10.1111/j.1095-8312.2009.01340.x

Ricca, M., Szövényi, P., Temsch, E.M., Johnson, M.G. \& Shaw, A.J. (2011) Interploidal hybridization and mating patterns in the Sphagnum subsecundum complex. Molecular Ecology 20: 3202-3218. https://doi.org/10.1111/j.1365-294X.2011.05170.x

Rieseberg, L.H. (1991) Homoploid reticulate evolution in Helianthus (Asteraceae) evidence from ribosomal genes. American Journal of Botany 78: 1218-1237. 
https://doi.org/10.1002/j.1537-2197.1991.tb11415.x

Rieseberg, L.H. (1995) The role of hybridization in evolution: old wine in new skins. American Journal of Botany 82: $944-953$.

https://doi.org/10.1002/j.1537-2197.1995.tb15711.x

Rieseberg, L.H. (1997) Hybrid origins of plant species. Annual Review of Ecology and Systematics 28: 359-389.

https://doi.org/10.1146/annurev.ecolsys.28.1.359

Rieseberg, L.H., Gerber, D. (1995) Hybridization in the Catalina mahogany: RAPD evidence. Conservation Biology 9: $199-203$. https://doi.org/10.1046/j.1523-1739.1995.09010199.x

Rieseberg, L.H., Whitton, J. \& Linder, C.R. (1996) Molecular marker incongruence in plant hybrid zones and phylogenetic trees. Acta Botanica Neerlandica 45: 143-262.

https://doi.org/10.1111/j.1438-8677.1996.tb00515.x

Risse, S. (1985) Pollia intermedia (Turn.) Fürnr. with rhizoidal tubers. Journal of Bryology 13: 523-526. https://doi.org/10.1179/jbr.1985.13.4.523

Roberts, H.F. (1929) Plant Hybridization before Mendel. Princeton, New Jersey: Princeton University Press. https://doi.org/10.5962/bhl.title.4517

Ros, R.M., Guerra, J. \& Cano, M.J. (1994) Pottia $\times$ andalusica (Musci: Pottiaceae), un híbrido interespecífico en Pottieae. Cryptogamie, Bryologie-Lichénologie 15: 199-204.

Ros, R.M., Guerra, J., Carrion, J.S. \& Cano, M.J. (1996) A new point of view on the taxonomy of Pottia starckeana agg. (Musci, Pottiaceae). Plant Systematics and Evolution 199: 153-165.

https://doi.org/10.1007/BF00984902

Rosengren, F. \& Cronberg, N. (2015) Selective spore germination on shoots of Homalothecium lutescens, a moss with dwarf males. Biological Letters 11: 20150427 https://doi.org/10.1098/rsbl.2015.0427

Rusek, J., Ayan, G.B., Turko, P., Telienbach, C., Giessler, S., Spaak, P. \& Wolinska, J. (2015) New possibilities arise for studies of hybridization: SNP-based markers for the multi-species Daphnia longispina complex derived from transcriptome data. Journal of Plankton Research 37: 626-635.

https://doi.org/10.1093/plankt/fbv028

Rushing, A.E. \& Snider, J.A. (1985) A natural hybrid between Bruchia microspora Nog., and Trematodon longicollis Michx. Monographs in systematics botany from the Missouri botanical garden 11: 121-132.

Sawangproh, W., Hedenäs, L., Lang, A.S., Hansson, B. \& Cronberg, N. (2020a) Gene transfer across species boundaries in bryophytes: evidence from major life cycle stages in Homalothecium lutescens and H. sericeum. Annals of Botany 125: 565-579.

https://doi.org/10.1093/aob/mcz209

Sawangproh, W., Lang, A.S., Hedenäs, L. \& Cronberg, N. (2020b) Morphological characters and SNP markers suggest hybridization and introgression in sympatric populations of the pleurocarpous mosses Homalothecium lutescens and H. sericeum. Organisms Diversity \& Evolution. https://doi.org/10.1007/s13127-020-00456-x

Såstad, S.M. (2005) Patterns and mechanisms of polyploid speciation in bryophytes. Regnum Vegetabile 143: 317- 334.

Såstad, S.M., Flatberg, K.I. \& Cronberg, N. (1999) Electrophoretic evidence supporting a theory of allopolyploid origin of the peatmoss Sphagnum jensenii. Nordic Journal of Botany 19: 355-362. https://doi.org/10.1111/j.1756-1051.1999.tb01127.x

Såstad, S. M., Flatberg, K.I. \& Hanssen, L. (2000) Origin, taxonomy and population structure of the allopolyploid peat moss Sphagnum majus. Plant Systematics and Evolution 225: 73-84.

https://doi.org/10.1007/BF00985459

Såstad, S.M., Stenøien, H.K., Flatberg, K.I. \& Bakken, S. (2001) The narrow endemic Sphagnum troendelagicum is an allopolyploid derivative of the widespread S. balticum and S. tenellum. Systematic Botany 26: 66-74.

Schmickl, R., Marburger, S., Bray, S. \& Yant, L. (2017) Hybrids and horizontal transfer: introgression allows adaptive allele discovery. Journal of Experimental Botany 68: 5453-5470. https://doi.org/10.1093/jxb/erx297

Schuster, R.M. (1966) The Hepaticae and Anthocerotae of North America East of the Hundreth Meridian, vol. 1. Columbia University Press, New York.

Schuster, R.M. (1988) The aims and achievements of bryophyte taxonomists. Botanical Journal of the Linnean Society 98: $185-202$. https://doi.org/10.1111/j.1095-8339.1988.tb02423.x

Shaw, A.J. (1994) Systematics of Mielichhoferia (Bryaceae: Musci). III. Hybridization between M. elongate and M. mielichhoferiana. American Journal of Botany 81: 782-790.

https://doi.org/10.1002/j.1537-2197.1994.tb15515.x 
Shaw, A.J. (1998) Genetic analysis of a hybrid zone in Mielichhoferia (Musci). In: Bates, J.W., Ashton, N.W. \& Duckett, J.G. (Eds.) Bryology for the twenty-first century. Maney Publishing and the British Bryological Society, Leeds, pp. 161-174. https://doi.org/10.1201/9781315138626-12

Shaw, A.J. (2009) Bryophyte species and speciation. In: Goffinet, B. \& Shaw, A.J. (Eds.) Bryophyte Biology, Cambridge: Cambridge University Press, pp. 445-485. https://doi.org/10.1017/CBO9780511754807.012

Shaw, A.J. \& Bartow, S.M. (1992) Genetic Structure and Phenotypic Plasticity in Proximate Populations of the Moss, Funaria hygrometrica. Systematic Botany 17: 257-271. https://doi.org/10.2307/2419521

Shaw, A.J., Boles, S. \& Shaw, B. (2008a) A phylogenetic delimitation of the “Sphagnum subsecundum complex” (Sphagnaceae, Bryophyta). American Journal of Botany 95: 731-744. https://doi.org/10.3732/ajb.0800048

Shaw, A.J., Cao, T., Wang, L.-S., Flatberg, K.I., Flatberg, B., Shaw, B., Zhou, P., Boles, S.B. \& Terraccino, S. (2008c) Genetic variation in three Chinese peat mosses (Sphagnum) based on microsatellite markers, with primer information and analysis of ascertainment bias. The Bryologist 111: 271-281. https://doi.org/10.1639/0007-2745(2008)111[271:GVITCP]2.0.CO;2

Shaw, A.J., Cox, C.J., Boles, S.B. \& Hoot, S.B. (2005) Phylogeny, species delimitation, and recombination in Sphagnum section Acutifolia. Systematic Botany 30: 16-33. https://doi.org/10.1600/0363644053661823

Shaw, A.J., Flatberg, K.I., Szövényi, P., Ricca, M., Johnson, M.G., Stenøien, H.K. \& Shaw, B. (2012a) Systematics of the Sphagnum fimbriatum complex: phylogenetic relationships, morphological variation, and allopolyploidy. Systematic Botany 63: 351-364.

Shaw, A.J. \& Goffinet, B. (2000) Molecular Evidence of Reticulate Evolution in the Peatmosses (Sphagnum), including S. ehyalinum sp. nov. The Bryologist 103: 357-374. https://doi.org/10.1639/0007-2745(2000)103[0357:MEOREI]2.0.CO;2

Shaw, A.J., Pokorny, L., Shaw, B., Ricca, M., Boles, S. \& Szövényi, P. (2008b) Genetic structure and genealogy in the Sphagnum subsecundum complex (Sphagnaceae: Bryophyta). Molecular Phylogenetics and Evolution 49: 304-317. https://doi.org/10.1016/j.ympev.2008.06.009

Shaw, A J., Shaw, B. \& Johnson, M.G. (2013) Origins, genetic structure and systematics of the narrow endemic peatmosses (Sphagnum): S. guwassanense and S. trieriporum (Sphagnaceae). American Journal of Botany 100: 1202-1220. https://doi.org/10.3732/ajb.1200630

Shaw, A J., Shaw, B. Ricca, M. \& Flatberg, K.I. (2012b) A phylogenetic monograph of the Sphagnum subsecundum complex (Sphagnaceae) in eastern North America. The Bryologist 115: 128-152. https://doi.org/10.1639/0007-2745-115.1.128

Shaw, A.J., Shaw, B., Stenøien, H.K., Golinski, G.K., Hassel, K. \& Flatberg, K.I. (2015) Pleistocene survival, regional genetic structure and interspecific gene flow among three northern peat-mosses: Sphagnum inexspectatum, S. orientale and S. miyabeanum. Journal of Biogeography 42: 364-376. https://doi.org/10.1111/jbi.12399

Smith, A.J.E. (1978) Cytogenetics, biosystematics and evolution in Bryophyta. Advances in Botanical Research 6: 195-276. https://doi.org/10.1016/S0065-2296(08)60331-6

Soltis, P.S. \& Soltis. D.E. (2009) The role of hybridization in plant speciation. Annual Review of Plant Biology 60: 561-588. https://doi.org/10.1146/annurev.arplant.043008.092039

Stace, C.A. (1987) Hybridization and the plant species. In: Urbanska, K.M. (Ed.) Differentiation patterns in higher plants. Academic Press, New York. 115-127 pp.

Stark, L.R. (1987) A taxonomic monograph of Forsstroemia Lindb. (Bryopsida: Leptodontaceae). Journal of the Hattori Botanical Laboratory 63: 133-218.

Stebbins, G.L. (1950) Variation and Evolution in Plants. New York: Columbia University Press. https://doi.org/10.7312/steb94536

Stech, M. \& Quandt, D. (2010) 20,000 species and five key markers: the status of molecular bryophyte phylogenetics. Phytotaxa 9 : $196-228$ https://doi.org/10.11646/phytotaxa.9.1.11

Stenøien, H.K. \& Flatberg, K.I. (2000) Genetic variability in the rare Norwegian peat moss Sphagnum troendelagicum. The Bryologist 103: 794-801. https://doi.org/10.1639/0007-2745(2000)103[0794:GVITRN]2.0.CO;2

Stenøien, H.K., Shaw, A.J., Stengrundet, K. \& Flatberg, K.I. (2011) The narrow endemic Norwegian peat moss Sphagnum troendelagicum 
originated before the last glacial maximum. Heredity 106: 370-382.

https://doi.org/10.1038/hdy.2010.96

Sukkharak, P., Gradstein, S.R. \& Stech, M. (2011) Phylogeny, taxon circumscriptions, and character evolution in the core Ptychanthoideae (Lejeuneaceae, Marchantiophyta). Taxon 60: 1607-1622.

https://doi.org/10.1002/tax.606006

Sytsma, K.J. (1990) DNA and morphology: inference of plant phylogeny. Trends in Ecology \& Evolution 5: 104-110. https://doi.org/10.1016/0169-5347(90)90163-8

Todesco, M., Pascual, M.A., Owens, G.L., Ostevik, K.L., Moyers, B.T., Hübner, S., Heredia, S.M., Hahn, M.A., Caseys, C., Bock, D.G. \& Rieseberg, L.H. (2016) Hybridization and extinction. Evolutionary Applications 9: 892-908. https://doi.org/10.1111/eva.12367

Ulychna, K.O. (1977) Hybrid sporogones in Phascum-Cuspidatum Pottiaceae Musci. Ukrayins'kyi Botanichnyi Zhurnal 34: $155-158$.

Vanderpoorten, A. \& Goffinet, B. (2009) Introduction to Bryophytes. Cambridge University Press, UK. https://doi.org/10.1017/CBO9780511626838

Vanderpoorten, A., Hedenäs, L. \& Jacquemart, A.L. (2003) Differentiation in DNA fingerprinting and morphology among species of the pleurocarpous moss genus Phytidiadelphus (Hylocomiaceae). Taxon 52: 229-236.

https://doi.org/10.2307/3647391

Vanderpoorten, A. \& Shaw, A.J. (2010) The application of molecular data to the phylogenetic delimitation of species in bryophytes: A note of caution. Phytotaxa 9: 229-237.

https://doi.org/10.11646/phytotaxa.9.1.12

van der Velde, M. \& Bijlsma, R. (2001) Genetic Evidence for the Allodiploid Origin of the Moss Species Polytrichum longisetum. Plant Biology 3: 379-385.

https://doi.org/10.1055/s-2001-16453

van der Velde, M. \& Bijlsma, R. (2004) Hybridization and asymmetric reproductive isolation between the closely related bryophyte taxa Polytrichum commune and P. uliginosum. Molecular Ecology 13: 1447-1454.

https://doi.org/10.1111/j.1365-294X.2004.02154.x

Vicente, M.C. de \& Tanksley, S.D. (1993) QTL analysis of transgressive segregation in an interspecific tomato cross. Genetics 134: $585-596$.

https://doi.org/10.1093/genetics/134.2.585

Vilnet, A., Konstantinova, N. \& Troitsky, A. (2012) Molecular phylogenetic data on reticulate evolution in the genus Barbilophozia Loske (Anastrophyllaceae, Marchantiophyta) and evidence of non-concerted evolution of rDNA in Barbilophozia rubescens allopolyploid. Phytotaxa 49: 6-22.

https://doi.org/10.11646/phytotaxa.49.1.2

Vogelmayer, H. (1998) Genome size analyses in mosses (Musci) and downy mildews (Peronosporales). PhD thesis, University of Vienna, Vienna.

von Wettstein, F. (1924) Morphologie und physiologie des formwechsels der moose auf genetischer grundlage I. Zeitschrift für inductive Abstammungs-und Vererbungeslehre 33: 1-236.

https://doi.org/10.1007/BF01762372

von Wettstein, F. (1928) Morphology and physiology of moss variation on a genetic basis. II. E Baur Bibliotheca Genetica X, 216 pp.

von Wettstein F. (1932) Genetik. In: Verdoorn, F. (Ed.) Manual of bryology. Hague: Martinus Nijhoff, pp. 233-272.

Vries, A. de, Bramer, J.P.J., Zanten, B.O. van, Hofman, A. \& Bijlsma, R. (1989) Allozyme Variation in Populations of Four Racopilum Species, including the Polyploid R. tomentosum. Lindbergia 15: 47-59.

Wagenitz, G. (2003) Wörterbuch der Botanik: Die Termini in ihrem historischen Zusammenhang. Spektrum Akademischer Verlag, Heidelberg.

Welsh, J. \& McClelland, M. (1990) Fingerprinting genomes using PCR with arbitrary primers. Nucleic Acid Research 18: 7213-7218. https://doi.org/10.1093/nar/18.24.7213

Werner, O., Köckinger, H., Magdy, M. \& Ros, R.M. (2014) On the systematic position of Tortella arctica and Trichostomum arcticum (Bryophyta, Pottiaceae). Nova Hedwigia 98: 273-293.

https://doi.org/10.1127/0029-5035/2014/0175

Whitham, T.G., Morrow, P.A. \& Potts, B.M. (1994) Plant hybrid zones as center for biodiversity: the herbivore community of two endemic Tasmanian eucalypts; Oecologia 97: 481-490. https://doi.org/10.1007/BF00325886

Williams, C. (1966) A natural hybrid in the genus Weissia. The Bryologist 69: 361-365. https://doi.org/10.2307/3240835

Wissemann, V. (2007) Plant evolution by means of hybridization. Systematic and Biodiversity 5: 243-253. 
https://doi.org/10.1017/S1477200007002381

Wojnicka-Poltorak, A., Chudzinska, E. \& Prus-Glowacki, W. (1997) Inter-and intraspecific serological relationships in Pellia epiphylla complex. Acta Societatis Botanicorum Poloniae 66: 365-370.

https://doi.org/10.5586/asbp.1997.045

Wyatt, R. (1994) Population genetics of bryophytes in relation to their reproductive biology. Journal of the Hattori Botanical Laboratory 76: $147-157$.

Wyatt, R. \& Odrzykoski, I.J. (1998) On the origins of the allopolyploid moss Plagiomnium cuspidatum. The Bryologist 101: $263-271$. https://doi.org/10.2307/3244203

Wyatt, R., Odrzykoski, I.J. \& Stoneburner, A. (1991) Chemosystematics of the Mniaceae. II. Flavonoids of Plagiomnium Section Rosultata. The Bryologist 94: 443-448. https://doi.org/10.2307/3243842

Wyatt, R., Odrzykoski, I.J. \& Stoneburner, A. (1992) Isozyme evidence of reticulate evolution in mosses: Plagiomnium medium is an allopolyploid of P. ellipticum $\times$ P. insigne. Systematic Botany 17: 532-550. https://doi.org/10.2307/2419725

Wyatt, R., Odrzykoski, I.J. \& Stoneburner, A. (1993a) Isozyme evidence regarding the origins of the allopolyploid moss Plagiomnium curvatulum. Lindbergia 18: 49-58.

Wyatt, R., Odrzykoski, I.J. \& Stoneburner, A. (1993b) Isozyme evidence proves that the moss Rhizomnium pseudopunctatum is an allopolyploid of $R$. gracile $\times$ R. magnifolium. Memoirs of the Torrey Botanical Club 25: 21-35.

Wyatt, R., Odrzykoski, I.J. \& Stoneburner, A. (2013) Isozyme evidence regarding the nature of polyploidy in the moss genus Cinclidium (Mniaceae). The Bryologist 116: 229-237.

https://doi.org/10.1639/0007-2745-116.3.229

Wyatt, R., Odrzykoski, I.J., Stoneburner, A., Bass, H.W. \& Galau, G.A. (1988) Allopolyploidy in bryophytes: multiple origins of Plagiomnium medium. Proceedings of the National Academy of Sciences, USA 85: 5601-5604. https://doi.org/10.1073/pnas.85.15.5601

Appendix A. References which have inferred hybridization during the period from January 1900 to September 2020. For each record information about phylum, family, major growth form, putative parental species (maternal and paternal species pointed out, if known), gametophytic hybrid species name (if any), type of hybridization (allopolyploid vs. homoploid; intra-vs. interspecific, intergeneric, intersectional etc.), quality of hybrid spores in F1 generation sporophytes (if known). The characters used for identifcation of hybrids in the gametophyte phase are also indicated as sporophyte, spore or gametophyte morphology, chemical markers (secondary metabolites), ploidy level identifiers, protein markers (isozymes or allozymes) and DNA markers. (Uploaded separately as Supplementary file) 